\title{
Immune cell populations residing in mesenteric adipose depots and mesenteric lymph nodes of lean dairy cows
}

\author{
B. A. Aylward, ${ }^{1}$ M. L. Clark, ${ }^{1 *}$ D. S. Galileo, ${ }^{2}$ A. M. Baernard, ${ }^{1}$ J. R. Wilson,,${ }^{1} \dagger$ E. Brannick, ${ }^{1}$ T. Gressley, ${ }^{1}$ \\ M. E. Fecteau, ${ }^{3}$ W. C. Davis, ${ }^{4}$ and R. M. Dyer ${ }^{1} \ddagger$ \\ ${ }^{1}$ Department of Animal and Food Sciences, College of Agriculture and Natural Resources, University of Delaware, Newark 19717-1303 \\ ${ }^{2}$ Department of Biological Sciences, University of Delaware, Newark 19717-1303 \\ ${ }^{3}$ George D. Widner Hospital for Large Animals, New Bolton Center, University of Pennsylvania School of Veterinary Medicine, 382 Street Road, \\ Kennett Square 19348 \\ ${ }^{4}$ Department of Veterinary Microbiology and Pathology, Washington State University, Pullman 99164-7040
}

\section{ABSTRACT}

Inconsistent evidence of inflammatory immune cell infiltrates in adipose tissues with extensive triglyceride mobilization raises the possibility that regulatory or anti-inflammatory immune cell populations reside within the mesenteric adipose tissue (MAT) and mesenteric lymph nodes (MLN). These resident immune cell populations may be involved in attenuating the inflammatory response. We explored the immune cell population of MAT and MLN collected from lean, lactating Holstein cows without apparent disease in an abattoir $(\mathrm{n}=42)$. Lean cows had a body condition score of $2.6 \pm 0.1$ (mean $\pm \mathrm{SD}$ ) with a greater frequency of adipocyte area occurring in small rather than large adipocytes. Cells were labeled with monoclonal antibodies specific to bovine leukocyte antigens for enumeration by flow cytometry. Within both lymph node and adipose tissues, relatively large subpopulations of cells expressed the $\beta 2$ integrins CD11b and CD11c, class II major histocompatibility antigens (MHCII), and the SIIRP-1 $\alpha$ receptor (CD172a) typical of dendritic cells and macrophages. Macrophage/dendritic cell heterogeneity was marked by $\beta 2$ integrin expression alone or in conjunction with CD172a or MHCII across subpopulations from both tissues; CD209, the DC-SIGN c-type lectin receptor of dendritic cells, was not detected by fluorescence-activated cell sorting in either tissue. Lymphocytes comprised $74.1 \pm 3.7 \%$ and $13.7 \pm 3.7 \%$ of the MLN and MAT cell populations, re-

Received June 4, 2018.

Accepted December 19, 2018.

*Current address: School of Veterinary Medicine and Immunology Graduate Program, Biomedical Graduate Studies, University of Pennsylvania, Philadelphia, PA 19104-6064.

$\dagger$ Current address: College of Veterinary Medicine, University of Florida, Gainesville, FL 32608.

$\ddagger$ Corresponding author: RDyer@UDel.edu spectively, and $\mathrm{CD} 3^{+} \mathrm{CD} 4^{+}$lymphocytes accounted for $49.8 \pm 9.9 \%$ of the MLN and $6.13 \pm 1.23 \%$ of the MAT cells. Fox $\mathrm{P}^{+}$regulatory lymphocytes comprised 15.3 $\pm 1.1 \%$ and $6.73 \pm 0.52 \%$ of the MLN and MAT cells, whereas $\gamma \delta^{+}$lymphocytes accounted for $6.65 \pm 0.74 \%$ and $3.91 \pm 0.43 \%$ of the MLN and MAT cells, respectively. Subpopulations of $\mathrm{CD} 3{ }^{+} \mathrm{CD} 8^{+}$cytotoxic $\mathrm{T}$ cells and $\mathrm{CD} 3{ }^{+} \mathrm{CD} 11 \mathrm{c}^{+}$innate lymphocytes were present in MLN but not MAT. These results show that subpopulations of resident tissue macrophages, dendritic cells, $\mathrm{T}$ helper lymphocytes, regulatory T lymphocytes (Tregs), and $\gamma \delta$ lymphocytes reside in mesenteric lymph nodes and adipose tissues. Balance in the innate and adaptive immune functions embedded in these tissues could support metabolic health.

Key words: mesenteric adipose, mesenteric lymph node, lymphocyte, macrophage, dendritic cell

\section{INTRODUCTION}

Compared with normally conditioned cows, overconditioned dairy cows are more prone to severe negative energy balance during the postpartum period (Dann et al., 2006; Janovick et al., 2011). Failure of homeorhetic regulation of metabolic activity during the postpartum period leads to dysregulated metabolic states and increased risk of metritis, ketonemia, displaced abomasum, retained placenta, and susceptibility to infection (Ospina et al., 2010). A signature event associated with insulin resistance in adipose depots of obese monogastrics is the induction of inflammation (Weisberg et al., 2003; Xu et al., 2003; Deiuliis et al., 2011) following reductions in resident regulatory or anti-inflammatory immune cells (Osborn and Olefsky, 2012; Mathis, 2013; Panduro et al., 2016) that normally counterbalance tissue inflammation (Mukesh et al., 2010; Vatier et al., 2012; Depreester et al., 2018). In contrast to monogastrics, results in bovines indicate that substantial numbers (Contreras et al., 2015) or trace amounts (Akter 
et al., 2012) of inflammatory cell infiltrates appear in postpartum adipose depots of overconditioned dairy cows. The conflicting findings suggest that inflammatory disease and insulin resistance in the adipose depot can be unpredictably divorced from metabolic disorders in overconditioned cows. This raises compelling questions about the degree of balance or imbalance in the immune homeostasis of resident adipose immune elements achieved across experimental designs.

Although much is known about the balance between regulatory and proinflammatory tissue-fixed immune elements and bystander adipose tissue injury (insulin resistance) in health or obesity, much less is known about the relationship between steady-state adiposefixed immune elements and mesenteric lymph node (MLN)-fixed immune elements or those trafficking to the MLN from the blood, adipose, and intestine tissues. Migratory dendritic cells and macrophages transport adipose tissue-specific (Weitman et al., 2013) or commensal microbial-specific antigens (Macpherson and Uhr, 2004; Mazmanian et al., 2005) to the draining MLN. In healthy, steady-state conditions, these cells promote regulatory or anti-inflammatory $\mathrm{T}$ lymphocyte (Treg) responses due to their highly tolergenic nature. These regulatory effector lymphocytes disseminate from the MLN back to the adipose tissue and intestine, where their regulatory activities rein in inflammation in the adipose depot and intestine mucosa (Lathrop et al., 2011; Cebula et al., 2013). The Treg in the adipose tissue prevent insulin resistance, whereas Treg in the MLN maintain oral tolerance to symbiotic intestinal commensals (Hadis et al., 2011) and sustain the integrity of intestinal permeability barriers (Strauch et al., 2005; Atarashi et al., 2011; Round et al., 2011). Populations of proinflammatory macrophages, dendritic cells, and $\mathrm{T}$ lymphocytes increase in MLN of adipose depots with hypertrophied adipocytes. Coincidently, the size of the Treg population decreases in these MLN (Magnuson et al., 2017). The pivotal function of MLN is to sustain immune homeostasis in the intestinal mucosa and secondarily to orchestrate steady-state homeostasis in the mesenteric adipose. These nodes would be expected to harbor dominant amounts of immune regulatory cell phenotypes in lean, healthy, steady-state dairy cows.

The presence of cluster of differentiation (CD) molecules on the cell surface allows identification of immune cell phenotypes. In bovines, macrophages and dendritic cells are identified by the expression of CD11b, CD11c, CD172a, CD209, and major histocompatibility complex class II (MHCII) molecules (Miyazawa et al., 2006; González-Cano et al., 2014). Macrophages and dendritic cells present antigen to naïve $\mathrm{T}$ cells to drive Tcell differentiation into regulatory, anti-inflammatory, or proinflammatory T-effector subsets identified by the expression of CD3, CD4, CD8, FoxP3, and $\gamma \delta$ (Murphy and Reiner, 2002).

We hypothesized that subpopulations of regulatory/ anti-inflammatory myeloid (macrophage/dendritic) and lymphoid ( $\mathrm{T}$ lymphocyte) cells reside in lean bovine mesenteric adipose tissue (MAT) and MLN. Thus, the objective of this work was to more completely characterize tissue-resident myeloid and lymphoid cell subpopulations in these tissues of lean dairy cows.

\section{MATERIALS AND METHODS}

\section{Animals and Tissue Samples}

Lactating, mature Holstein cows lacking gross evidence of diseases $(n=42)$ were randomly selected from an abattoir population at the time of entry onto the slaughterhouse floor. An experienced bovine veterinarian (R. Dyer) evaluated every cow for clinical evidence of lameness and external, gross lesions. Cows lacking external evidence of disease were assigned a BCS (Ferguson et al., 1994) before slaughter. Animals with BCS 2.0 to 3.5 were chosen for tissue analysis.

\section{Tissue Harvest}

After killing animals by captive bolt, a single veterinarian (R. Dyer) evaluated all viscera to exclude any animals with evidence of septic intra-abdominal, thoracic, intrauterine, intramammary, or gastrointestinal disorders. Then, MLN and MAT were collected within 15 min of death after removal of the viscera from the carcass. Adipose tissue was excised from the great mesentery 15 to $20 \mathrm{~cm}$ from the mesenteric border of the jejunum and midway down the full length of the jejunum. The tissue was trimmed into pieces of approximately $30 \mathrm{~g}$ and placed in $150 \mathrm{~mL}$ of sterile PBS with $10 \mathrm{mM}$ HEPES, pH $7.35\left(38^{\circ} \mathrm{C}\right)$, for cell phenotyping. Hardening of the fat during transport (45 min) to the laboratory was prevented by placing MAT in an insulated box containing $38^{\circ} \mathrm{C}$ water. Mesenteric lymph nodes were removed from the mid-jejunum mesentery located within 7 to $10 \mathrm{~cm}$ of the adipose sample. Adipose tissue was trimmed off the MLN capsule and the node was placed in $150 \mathrm{~mL}$ of sterile PBS with $10 \mathrm{~m} M$ HEPES, $\mathrm{pH} 7.35\left(4^{\circ} \mathrm{C}\right)$, for cell phenotyping. The MLN samples were placed on ice and transported to the laboratory within $45 \mathrm{~min}$.

\section{Isolation of MAT Stromal Cell Fraction and MLN Cells}

Isolation of MAT Stromal Cell Fraction. All MAT samples were maintained at $38^{\circ} \mathrm{C}$ throughout tissue preparation. Six 1-g samples of MAT (6 g total of 
MAT from a cow) were finely minced with a sterile scalpel in a sterile glass Petri dish. Any vascular structures were dissected from the adipose tissue and discarded. Minced MAT was transferred to $50 \mathrm{~mL}$ of PBS with 10 $\mathrm{m} M$ HEPES ( hereafter, PBS-HEPES; $38^{\circ} \mathrm{C}, 1.0 \mathrm{~g}$ of adipose per $50 \mathrm{~mL}$ of PBS) and washed once (10 min, $\left.800 \times g, 25^{\circ} \mathrm{C}\right)$ in $50 \mathrm{~mL}$ of PBS-HEPES to remove blood contamination. Washed, minced MAT (1 g) was digested in flasks containing $2 \mathrm{~mL}$ of PBS-HEPES and 4 $\mathrm{mg} / \mathrm{mL}$ collagenase type II (Sigma Chemical, St. Louis, $\mathrm{MO} ; 38^{\circ} \mathrm{C}$ ). The flasks were placed in a $38^{\circ} \mathrm{C}$ incubator and shaken $(150 \mathrm{rpm} / \mathrm{min})$ for $60 \mathrm{~min}$. Supernatants were transferred to glass wool columns and the flasks washed 3 to 4 times with $5 \mathrm{~mL}$ of PBS-HEPES, $38^{\circ} \mathrm{C}$. Eluents from the column were collected, and the cells were pelleted $\left(1,000 \times g, 25^{\circ} \mathrm{C}, 20 \mathrm{~min}\right)$, pooled into one pellet, and washed (PBS-HEPES, $4^{\circ} \mathrm{C}$ ). Pooled cells were suspended in divalent cation-free PBS with $10 \%$ acid citrate dextrose (ACD) and layered on top of a Percoll gradient (Sigma Chemical) consisting of $1.029 \mathrm{~g}$ of Percoll $/ \mathrm{mL}$ over $1.10 \mathrm{~g}$ of Percoll $/ \mathrm{mL}$. Gradients were centrifuged $\left(20 \mathrm{~min}, 25^{\circ} \mathrm{C}, 1,200 \times g\right)$ and the cell-enriched layer collected at the Percoll gradient interface. Cells were washed in divalent cation-free PBS with $10 \%$ ACD. Aliquots of cells were counted and suspended in trypan blue for viability $(84.5 \pm 0.02 \%$ live; mean \pm SEM). Finally, the cell concentrations were adjusted to $1.0 \times 10^{7}$ viable cells $/ \mathrm{mL}$ of divalent cation-free PBS with $10 \% \mathrm{ACD}$ and $2 \%$ equine serum (ES; Sigma Chemical) at $4^{\circ} \mathrm{C}$.

Isolation of MLN Cells. The MLN were placed in sterile Petri dishes containing PBS-HEPES $\left(4^{\circ} \mathrm{C}\right)$ and minced with scraping using a sterile scalpel blade. The minced MLN were repeatedly suspended in PBSHEPES $\left(4^{\circ} \mathrm{C}\right)$ and the cell-enriched supernatants placed onto glass wool columns. Eluents were collected and cells washed once (PBS-HEPES at $4^{\circ} \mathrm{C} ; 1,000 \times g, 30$ min, $25^{\circ} \mathrm{C}$ ). Contaminating red blood cells were lysed (sterile distilled $\mathrm{H}_{2} \mathrm{O}, 25 \mathrm{~s}$ ), the MLN cells were washed 3 times (PBS-HEPES), and the pellets suspended in divalent cation-free PBS with $10 \% \mathrm{ACD}$ and $2 \% \mathrm{ES}\left(4^{\circ} \mathrm{C}\right.$; hereafter, PBS-ACD-ES) at $1.0 \times 10^{7}$ viable cells $/ \mathrm{mL}$.

\section{Immune Cell Staining of CD Markers}

Murine anti-bovine leukocyte antigen-specific mAb (Washington State Monoclonal Antibody, Washington State University, Pullman, WA) were used across all procedures (Table 1). Stock solutions of primary antibodies were prepared by dilution $(15 \mu \mathrm{g} / \mathrm{mL})$ in PBS-ACD-ES. Stock solutions of each $\mathrm{mAb}$ were serially diluted in PBS-ACD-ES with the final dilution in complement-inactivated normal bovine serum. Preliminary work indicated that $50 \%$ complement-inactivated bovine serum blocked the Fc receptor and nonspecific binding of all isotype and protein-matched irrelevant primary control antibodies. Secondary antibody reagents were fluorescein isothiocyanate (FITC)- or phycoerythrin (PE)-conjugated caprine anti-murine $\operatorname{IgG}_{1}, \quad \operatorname{Ig} G_{2 \mathrm{a}}, \operatorname{Ig} \mathrm{G}_{2 \mathrm{~b}}, \operatorname{IgG}_{3}$, and $\operatorname{IgM}$ (Jackson ImmunoResearch Laboratories, West Grove, PA). Secondary reagents were diluted 1:100 in PBS-ACD-ES with 10 $\mathrm{m} M$ HEPES, and were used at a working dilution of 1:200 in the final reaction. A final working amount of $5 \%$ complement-inactivated normal goat serum (Jackson ImmunoResearch) blocked nonspecific binding of conjugated secondary antibodies. All primary and secondary antibody reactants $(100 \mu \mathrm{L})$ were added to wells of a 96-well, V-bottom microtiter plate with $1.0 \times 10^{6}$ viable cells $(100 \mu \mathrm{L})$ to achieve a final reaction volume of $200 \mu \mathrm{L} /$ well. Control wells included cells in wash buffer only, cells in primary murine $\mathrm{mAb}$ of no known reactivity (Life Technologies, Carlsbad, CA) matched by isotype and amount of protein to the primary leukocyte-specific mAb (Table 1), and a final working dilution (1:200) of secondary FITC- or PEconjugated goat anti-murine isotype-specific antibody. Both primary and secondary antibody reactions were performed at $4^{\circ} \mathrm{C}$ for $30 \mathrm{~min}$, followed by 3 washes in PBS-ACD-ES, with vortexing (10 s) between each wash. All cell preparations were fixed in PBS with $2 \%$ phosphate-buffered formaldehyde $\left(4^{\circ} \mathrm{C}, 16 \mathrm{~h}\right)$ and passed into tubes through a $35-\mu \mathrm{m}$ cell strainer cap.

For intracellular Fox P3 detection, cells stained for cell surface markers and fixed in $2 \%$ formaldehyde (16 $\mathrm{h}, 4^{\circ} \mathrm{C}$ ) were permeabilized by incubation in fixation/ permeabilization buffer (eBiosciences, San Diego, CA; $60 \mathrm{~min}, 4^{\circ} \mathrm{C}$ ) and then washed in PBS-ACD-ES. Permeabilized cells were stained with murine monoclonal anti-bovine FoxP3 following procedures previously outlined for primary and secondary reactions.

Flow Cytometric Analysis. Cell analysis was performed on a BD fluorescence-activated cell sorter (FACS) Calibur System using the BD Cell Quest Pro Software (BD Biosciences, San Juan, CA). Forward and side scatter thresholds were set to optimize scatter of the MAT stromal cell fraction (SCF) and MLN cell preparations and to eliminate unnecessary debris. Gating was established for the populations of interest within the MAT SCF and MLN cells (data not shown). Fluorescent detectors were adjusted using unstained control preparations and the isotype- and protein-matched control preparations for each set of cells. Compensation settings were adjusted for single FITC- or PE-stained cells to minimize spectral overlap and place the stain of interest in the appropriate position on the green (FL1) or red (FL2) axis. Data acquisition was performed until 10,000 gated events were counted. 
Table 1. Monoclonal antibodies, specificities, and dilution of primary antibody stock

\begin{tabular}{llll}
\hline Specificity $^{1}$ & $\begin{array}{l}\text { Monoclonal antibody } \\
\text { catalog number }\end{array}$ & Isotype & $\begin{array}{l}\text { Final working } \\
\text { dilution }\end{array}$ \\
\hline CD3 & MM1A & $\operatorname{IgG}_{1}$ & $1: 4$ \\
CD172a & DH59B & $\operatorname{IgG}_{1}$ & $1: 4$ \\
CD11b & MM10A & $\operatorname{IgG}_{2 \mathrm{~b}}$ & $1: 32$ \\
CD8 $\alpha$ & CACT130A & $\operatorname{IgG}_{3}$ & $1: 4$ \\
CD4 & IL11A & $\operatorname{IgG}_{2 \mathrm{a}}$ & $1: 32$ \\
$\gamma \delta$ TCR1-N24 & G-GB21A & $\operatorname{IgG}_{2 \mathrm{~b}}$ & $1: 32$ \\
FoxP3 & Fox5A & $\operatorname{IgG}_{1}$ & $1: 4$ \\
MHCII & TH14B & $\operatorname{IgG}_{2 \mathrm{a}}$ & $1: 32$ \\
CD209 & 209MD26A & $\operatorname{IgG}_{2 \mathrm{a}}$ & $1: 8$ \\
CD11c & BAQ153A & $\operatorname{IgM}$ & $1: 4$ \\
CD11c & BAQ151A & $\operatorname{IgG}_{1}$ & $1: 4$ \\
Isotype control & & & \\
None & MG100 & $\operatorname{IgG}_{1}$ & $1: 4$ \\
None & MGM00 & $\operatorname{IgM}_{2}$ & $1: 4$ \\
None & PA5-33223 & $\operatorname{IgG}_{2 \mathrm{~b}}$ & $1: 32$ \\
None & PA5-33236 & $\operatorname{IgG}_{2 \mathrm{a}}$ & $1: 32$ \\
None & MA1-10433 & $\operatorname{IgG}_{3}$ & $1: 4$ \\
\hline
\end{tabular}

${ }^{1} \mathrm{CD}=$ cluster of differentiation; $\mathrm{MHC}=$ major histocompatibility complex.

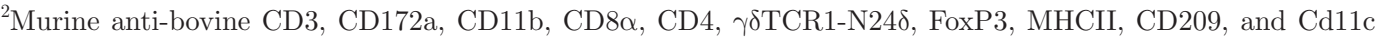
from Monoclonal Antibody Center, Washington State University (Pullman, WA). Isotype controls Mg100, MGM00, Pa5-33223, Pa5-33236, and MA1-10433 from Life Technologies (Carlsbad, CA).

Adipocyte Size Histomorphometry. Lactating, mature Holstein cows lacking gross evidence of diseases $(\mathrm{n}=53)$ were randomly selected from an abattoir population at the time of slaughter. Some animals (BCS $\leq 3.5, \mathrm{n}=42$ ) included those used for MAT SCF and MLN cell isolation but others (BCS $>3.0$ ) were separate from the set used for cell isolation. Samples of MAT $\left(1 \mathrm{~cm}^{2}\right)$ were removed from the same site as used for MAT SCF isolation and placed in $3 \%$ phosphate-buffered formaldehyde to determine adipose area. Fixed MAT was trimmed, embedded in paraffin, sectioned at $5 \mu \mathrm{m}$, placed on glass slides, and stained with hematoxylin and eosin. Adipocyte surface area was determined on 10 randomly selected adipocytes along the diagonal in each of 10 randomly selected $40 \times$ fields (100 total adipocytes) for each MAT specimen using a Nikon DS-F2 camera and NIS Elements D image analysis software (Nikon Instruments Inc., Melville, NY). Accordingly, adipocyte area was determined as the mean of 100 randomly selected adipocytes for each MAT. Frequency distribution of adipocyte area was determined within successive areas of $1,000 \mu \mathrm{m}^{2}$ and expressed as percent total counts $(\mathrm{n}=5,300$ and 4,200 for all cows across all BCS and cows used for MAT SCF phenotype, respectively).

\section{Statistical Analysis}

For FACS, the level of fluorescence above background was evaluated by one-tailed Student's $t$-test. Fluorescent differences across MLN and MAT SCF were evalu- ated by one-tailed Student's $t$-test. The correlation between BCS and adipocyte area was determined using the Pearson product-moment correlation coefficient $t$ test for correlations. Differences between means were declared at $P \leq 0.05$.

\section{RESULTS}

Adipocyte area correlated with BCS $(\mathrm{r}=0.49, P$ $\leq 0.05, \mathrm{n}=53$ ). Body condition score and the area of MAT adipocytes used for FACS analysis were 2.6 \pm 0.1 and $4,971.07 \pm 395 \mu^{2}$, respectively $(\mathrm{n}=42)$. Smaller adipocytes occurred with greater frequency than larger adipocytes in the MAT across both populations of cows. Numerically higher frequencies of smaller adipocytes occurred in the adipose tissues of cows used for isolation of MAT SCF (Figure 1). These outcomes are consistent with a moderately lean body condition and trends for smaller adipocytes of visceral adipose depots in later lactation (Akter et al., 2011; Kenez et al., 2015).

\section{Myeloid Cells Are Indigenous Members of the Core Bovine MAT SCF and MLN Cell Populations}

The cell surface markers CD11b, CD11c, CD172a, CD209, and MHCII are primarily but not exclusively expressed on cells from the macrophage and dendritic cell (myeloid) series. The $\beta 2$ integrin CD11b was expressed in (mean \pm SEM) $24.9 \pm 2.4 \%$ of the MLN and $13.9 \pm 4.3 \%$ of the MAT SCF cell population (Figure 


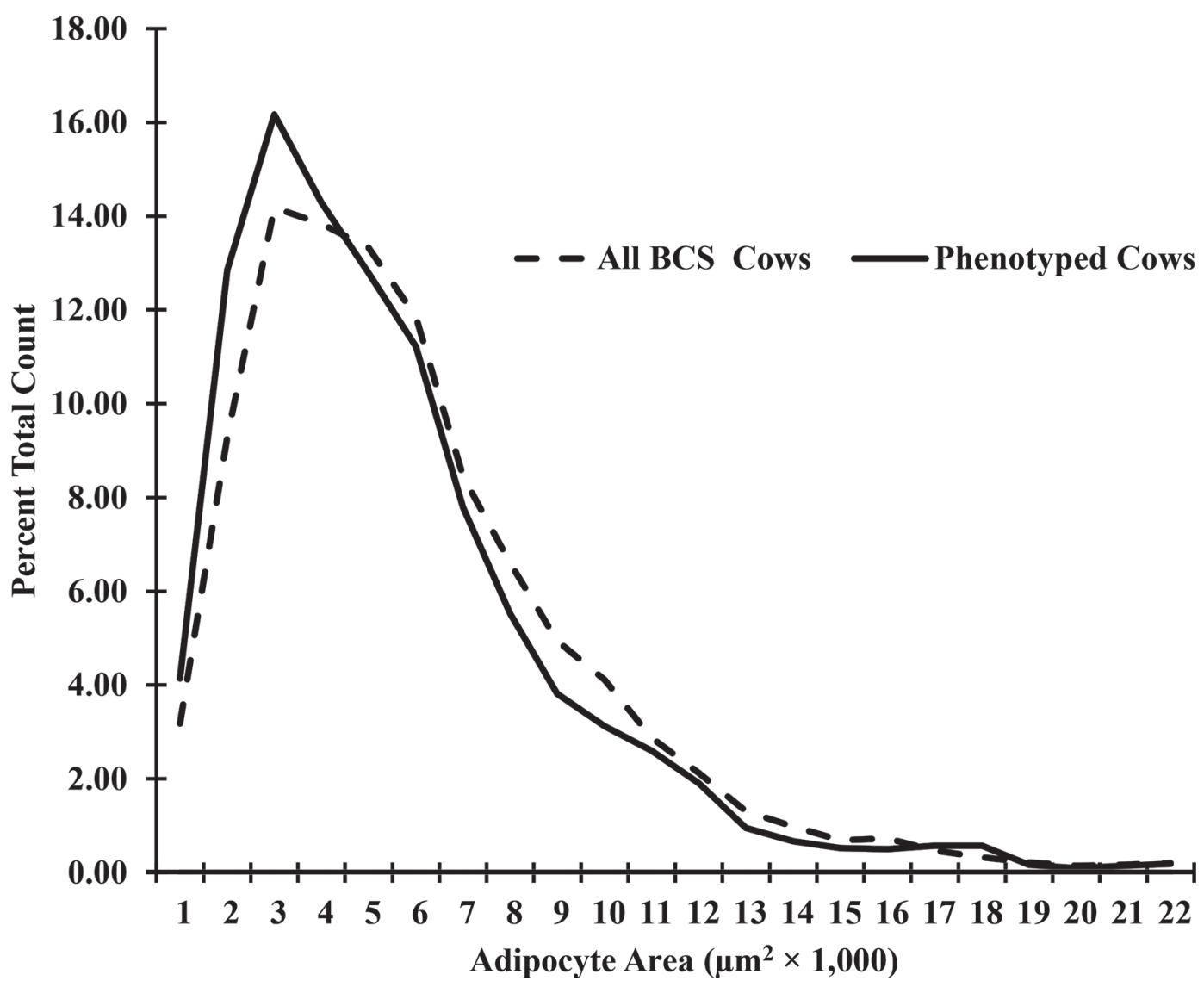

Figure 1. Frequency distribution of mesenteric adipose depot adipocyte area expressed as percent of total cell count for cows across all BCS $(\mathrm{n}=53)$ and cows used for mesenteric adipose tissue stromal cell fraction phenotype $(\mathrm{n}=42)$.

2, Supplemental Figure S1; https://doi.org/10.3168/ jds.2018-15156). Expression of CD11b was 1.79-fold greater in MLN than in MAT SCF $(P \leq 0.05)$.

Expression of CD172a, the signal regulatory phosphatase (SIRP) binding receptor, occurred in 6.37 $\pm 0.90 \%$ of the MLN and $16.3 \pm 5.0 \%$ of the MAT SCF populations (Figure 2, Supplemental Figure S1). Interestingly, CD172a expression was 2.5-fold greater $(P \leq 0.05)$ in the MAT SCF $(16.3 \pm 5.0 \%)$ than in the MLN. Because bovine myeloid or dendritic cells express CD11b and CD172a (Miyazawa et al., 2006; GonzálezCano et al., 2014), the coordinated expression of these 2 proteins in MLN and MAT SCF was of interest. Coexpression of CD11b and CD172a occurred in only 5.00 $\pm 0.59 \%$ of the MLN and $7.11 \pm 2.07 \%$ of the MAT SCF cell populations (Figure 2) in these cows. Within the CD172a ${ }^{+}$populations, the fraction of cells $(76.2 \pm$ $4.1 \%)$ that expressed $\mathrm{CD}_{11 \mathrm{~b}^{+}}$was greater in the MLN $(42.9 \pm 9.3 \%)$ than in the MAT SCF $(P \leq 0.05$, Figure 2 ). Moreover, $6.74 \pm 1.00 \%$ of the MLN cell population was $\mathrm{CD} 172 \mathrm{a}^{+}, \mathrm{CD}_{11 \mathrm{~b}}^{-}$, with a much larger percentage $(17.27 \pm 3.07 \%)$ of the MAT SCF population expressing CD172a in the absence of the CD11b integrin (Figure
$2 ; P \leq 0.05)$. Thus, CD172a expression was greatest in the MAT SCF, occurred evenly within the $\mathrm{CD}_{11 \mathrm{~b}}{ }^{+}$cell populations in both the MAT SCF and MLN, and was higher in the $\mathrm{CD}_{11 b^{-}}$cell populations in MAT SCF. We also assessed co-expression of CD11b with CD209, the DC-SIGN C-type lectin receptor expressed on myeloid-derived, conventional dendritic cells, and some macrophages (Figure 3, Supplemental Figure S1; https: //doi.org/10.3168/jds.2018-15156). Subpopulations of cells from both the MLN and MAT SCF expressed CD11b as described above. Expression of CD209 and therefore CD11b CD209 co-expression was not detected in the MLN or MAT SCF cell populations (Figure 3, Supplemental Figure S1).

We evaluated CD11c and MHCII expression on myeloid subpopulations in the MLN and MAT SCF. A subpopulation of MLN cells $(25.7 \pm 0.6 \%)$ and MAT SCF cells $(9.83 \pm 0.57 \%)$ expressed CD11c (Supplemental Figure S2; https://doi.org/10.3168/jds.2018 -15156), and MHCII was a dominant cell surface protein $(20.0 \pm 1.53 \%$; Supplemental Figure S3, https:/ /doi.org/10.3168/jds.2018-15156) in the MLN. Compared with MLN cells, a smaller subpopulation (10.8 
A)

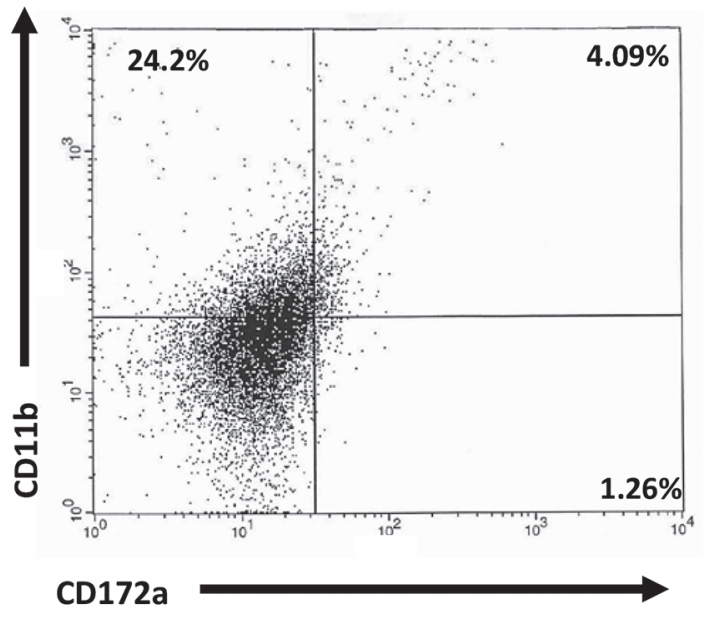

B)

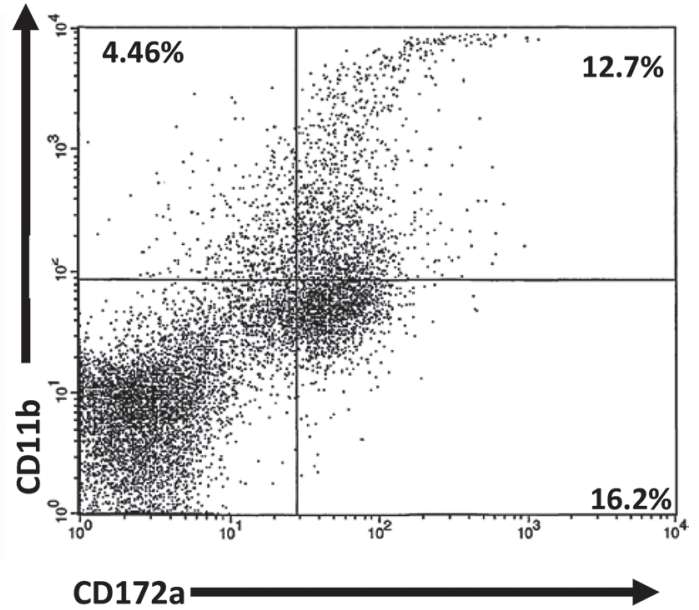

C)

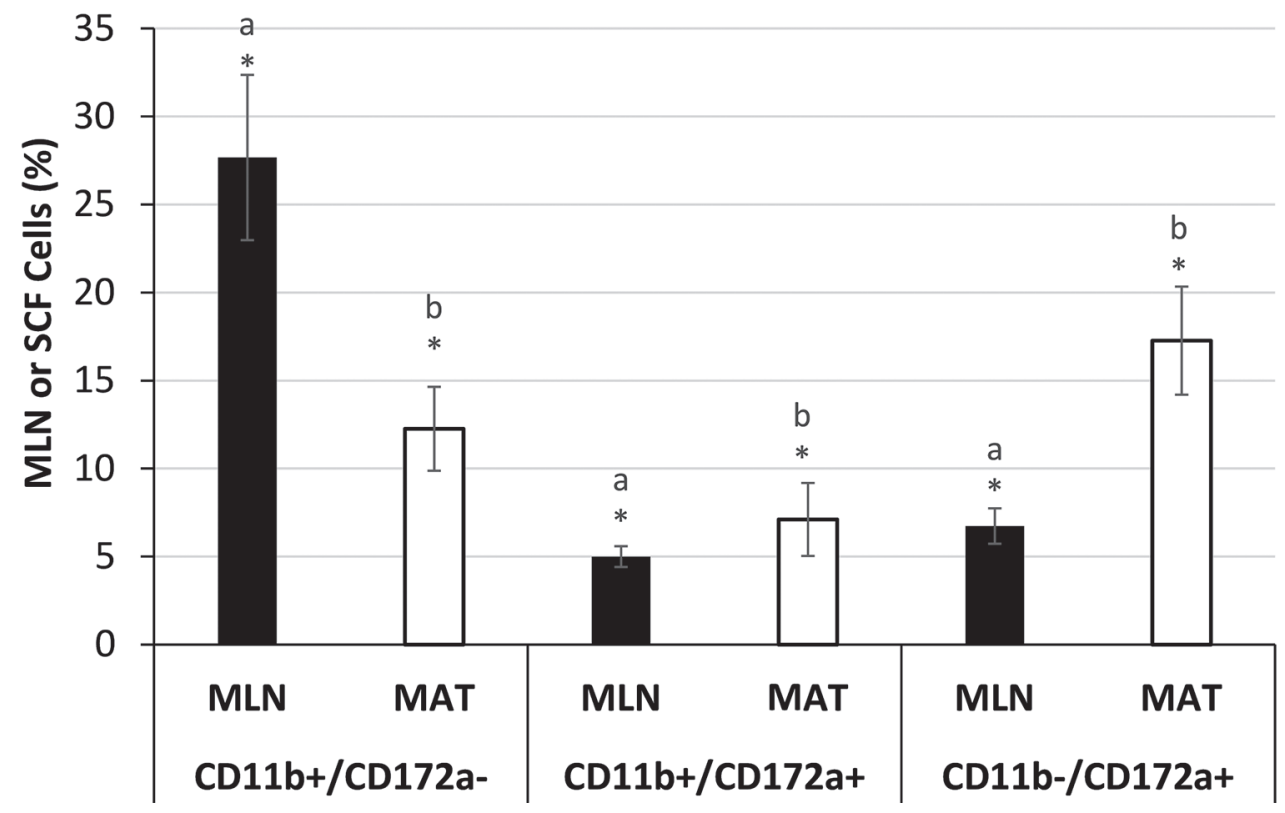

Figure 2. Representative fluorescence-activated cell sorting plots of cluster of differentiation (CD)11b and CD172a co-expression in mesenteric lymph node (MLN; A) and mesenteric adipose tissue (MAT) stromal cell fraction (SCF; B) and percent of cells positive for CD11b, for CD11b and CD172a, or for CD172 in MLN and MAT $(\mathrm{n}=5$; C). Data are expressed as mean \pm SEM. Means with different letters $(\mathrm{a}$, b) within staining group differ $(P \leq 0.05)$ and means with $*$ differ from background staining $(P \leq 0.05)$.

$\pm 0.8 \%)$ of the MAT SCF $(P \leq 0.05)$ expressed MHCII (Supplemental Figure S3; $P \leq 0.05)$. In contrast, $\mathrm{MHCII}^{+} \mathrm{CD}_{11 \mathrm{c}^{+}}$co-expression occurred in a relatively smaller subpopulation $(10.0 \pm 0.6 \%)$ of the MLN and an even smaller population $(1.16 \pm 0.37 \%)$ of the MAT SCF (Figure $4 ; P \leq 0.05$ ). Altogether, cell populations spanning the $\mathrm{CD} 11 \mathrm{c}^{+} \mathrm{MHCII}^{+}, \mathrm{CD}_{11 \mathrm{C}^{+}} \mathrm{MHCII}^{-}$, and $\mathrm{CD}_{11 \mathrm{c}^{-}} \mathrm{MHCII}^{+}$phenotypes existed in MLN and MAT. The relative size of the different CD11c and MHCII

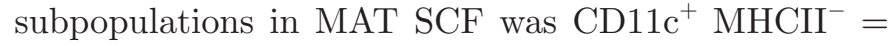

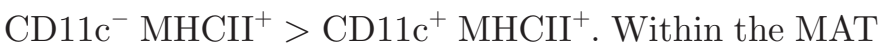
CD11c ${ }^{+}$cell populations, the $\mathrm{CD}_{11 \mathrm{c}^{+}} \mathrm{MHCII}^{-}$pool of cells $(5.92 \pm 1.64 \%)$ was 5 -fold greater than the population of CD11c ${ }^{+} \mathrm{MHC} \mathrm{II}^{+}$cells $(1.16 \pm 0.37 \%$; Figure 4 , $P \leq 0.05)$. The MHC $\mathrm{II}^{+} \mathrm{CD} 11 \mathrm{c}^{-}$subpopulation (4.66 $\pm 1.40 \%)$ was 4 -fold larger than the $\mathrm{MHCII}^{+} \mathrm{CD} 1 \mathrm{c}^{+}$ subpopulation in the MAT SCF (Figure $4, P \leq 0.05$ ). In the MLN, the relative size of the subpopulations was

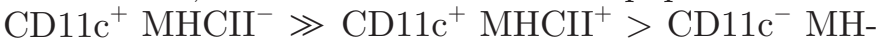
$\mathrm{CII}^{+}$. Within the MLN CD11c ${ }^{+}$cell populations, the 


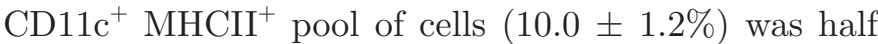
the size of the CD11c ${ }^{+}$MHCII $^{-}$cell population $(20.2 \pm$ $2.4 \%$; Figure $4, P \leq 0.05$ ).

\section{Lymphocytes Are Dominant Members of the Core Resident Bovine MAT SCF and MLN Cell Populations}

As expected, most $(74.1 \pm 3.7 \%)$ of the MLN cell populations consisted of $\mathrm{CD}^{+}$lymphocytes. In contrast, only $13.7 \pm 3.7 \%$ of the MAT SCF consisted of $\mathrm{CD}^{+}$lymphocytes (Supplemental Figure S4; https:// doi.org/10.3168/jds.2018-15156). The size of the MLN lymphocyte population was considerably greater than that of the MAT SCF $(P<0.05)$. To characterize the lymphocyte phenotypes further, we used FACS analysis of the SCF stained with anti-CD4, anti-CD8, and anti$\gamma \delta$ antibodies. In the MLN, $48.02 \pm 3.0 \%$ of the cells were $\mathrm{CD}^{+}$; a much smaller portion $(7.78 \pm 0.49 \%)$ of the MAT SCF population was $\mathrm{CD}^{+}$(Supplemental Figure S5; https://doi.org/10.3168/jds.2018-15156; $P<$ 0.05). A CD $3{ }^{+} \mathrm{CD} 4^{+}$double-positive cell population accounted for $49.8 \pm 9.9 \%$ of the MLN cells and a smaller double-positive cell population was detected in the MAT SCF $(6.13 \pm 1.23 \%$; Figure $5 ; P<0.05)$. These

B)
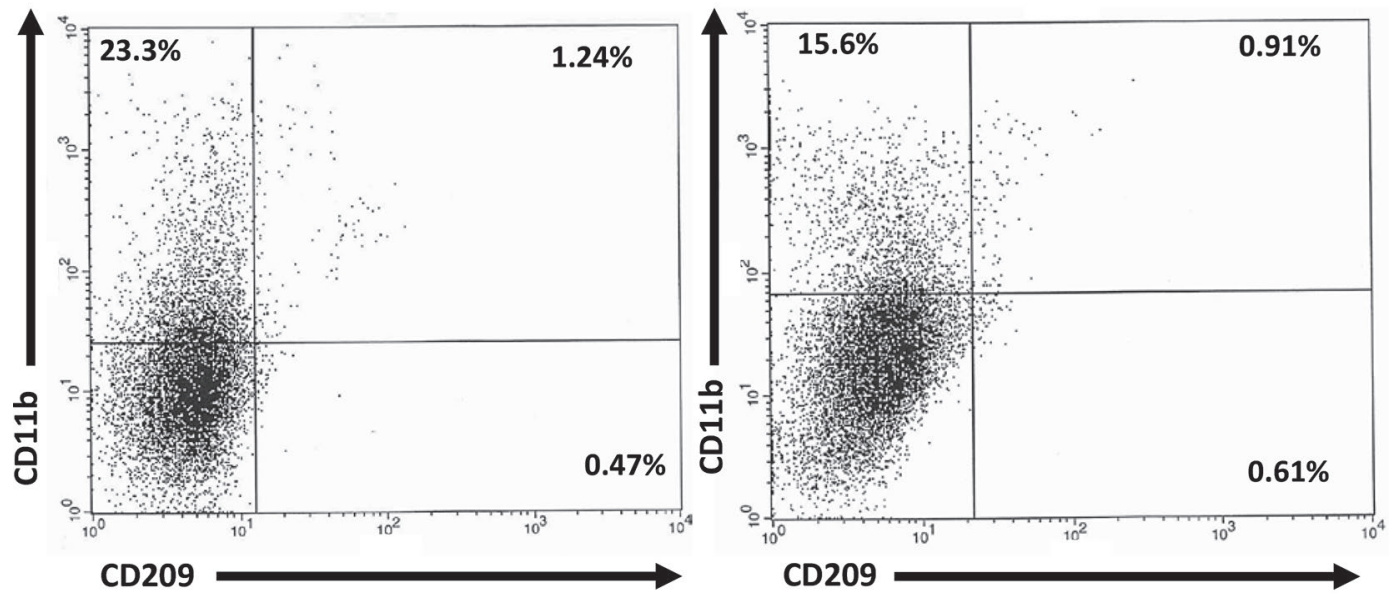

C)

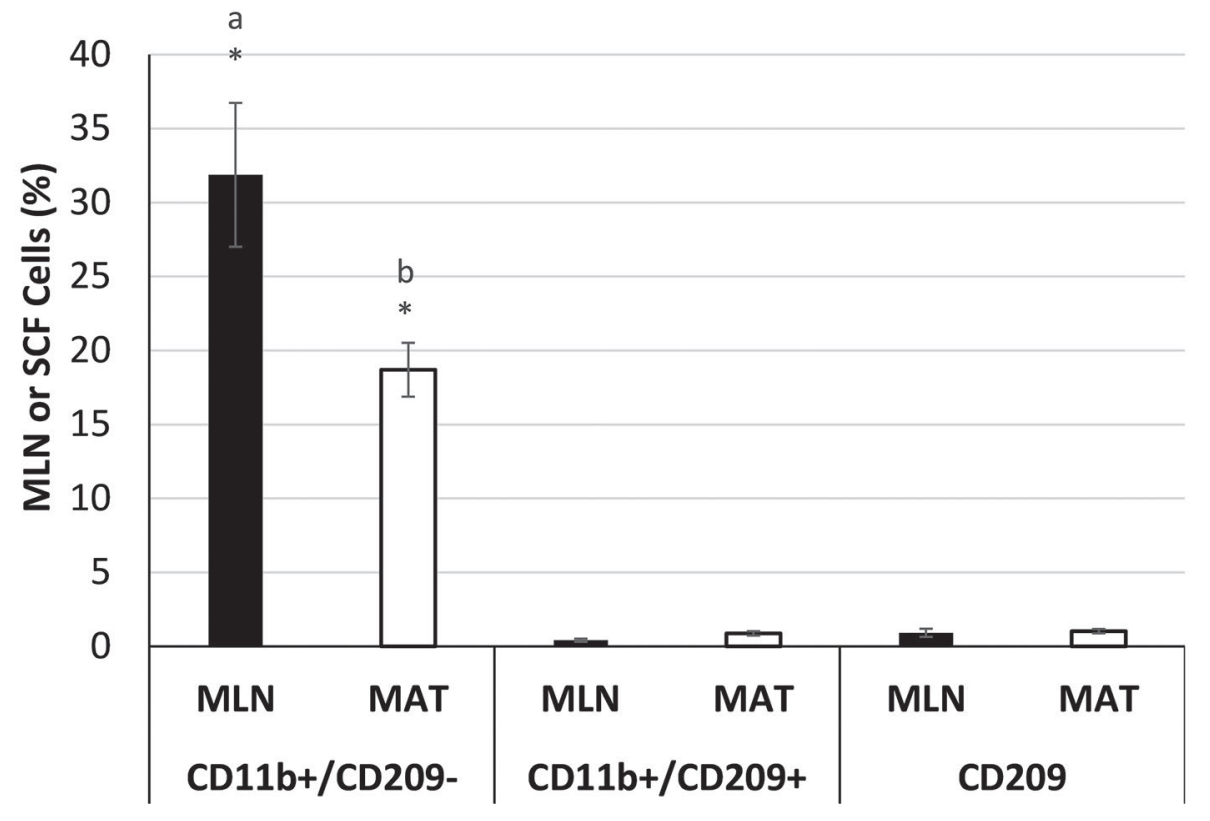

Figure 3. Representative fluorescence-activated cell sorting plots of cluster of differentiation (CD)11b and CD209 co-expression in the mesenteric lymph node (MLN; A) and mesenteric adipose tissue (MAT) stromal cell fraction (SCF; B) and percent of cells positive for CD11b, for CD11b and CD209, or for CD209 in the MLN and MAT SCF $(n=5 ;$ C). Data are expressed as mean \pm SEM. Means with different letters (a, b) within staining group differ $(P \leq 0.05)$ and means with * differ from background staining $(P \leq 0.05)$. 
results show that approximately $65 \%$ (48.0\% of $74.1 \%)$ of the $\mathrm{CD}^{+} \mathrm{T}$ lymphocyte cell lineage in the MLN co-expressed CD4 ${ }^{+}$. Similarly, $45.1 \%$ (6.1\% of $13.7 \%$ ) of the $\mathrm{CD}^{+} \mathrm{T}$ lymphocyte lineage in the MAT SCF was $\mathrm{CD} 3^{+} \mathrm{CD} 4^{+}$double positive. The $\mathrm{CD} 8^{+}$subpopulation within the MLN accounted for $17.49 \pm 1.99 \%$ of the cell population. In contrast, only $2.52 \pm 1.22 \%$ of the MAT SCF population was CD8 ${ }^{+}$(Supplemental Figure S6; https://doi.org/10.3168/jds.2018-15156). The MLN cell populations consisted of $12.97 \pm 3.35 \% \mathrm{CD}^{+} \mathrm{CD}^{+}$ double-positive lymphocytes. Only $1.07 \pm 0.52 \%$ of the MAT SCF cells were $\mathrm{CD} 3^{+} \mathrm{CD} 8^{+}$double positive
(Supplemental Figure S6). The number of $\mathrm{CD}^{+}$and $\mathrm{CD}^{+} \mathrm{CD}^{+}$cells in the MAT SCF was no greater than background staining $(P>0.05)$. The ratio of $\mathrm{CD} 4$ to CD8 lymphocytes within the $\mathrm{CD}^{+}$pool of cells was approximately 3.8 in MLN and $>42.1$ in MAT SCF.

Suspensions of MLN cells also contained $15.3 \pm$ $1.1 \% \mathrm{FoxP}^{+}$cells, whereas MAT SCF expressed FoxP3 in $6.73 \pm 0.52 \%$ of cells (Figure 6 ). In addition, $\mathrm{CD}^{+} \mathrm{FoxP}^{+}$double-positive cells comprised $4.64 \pm 0.58 \%$ of the MLN cell populations and 0.03 $\pm 0.01 \%$ of the MAT SCF (Figure 6 ). The amount of double-positive staining cells in the MAT SCF was no
A)

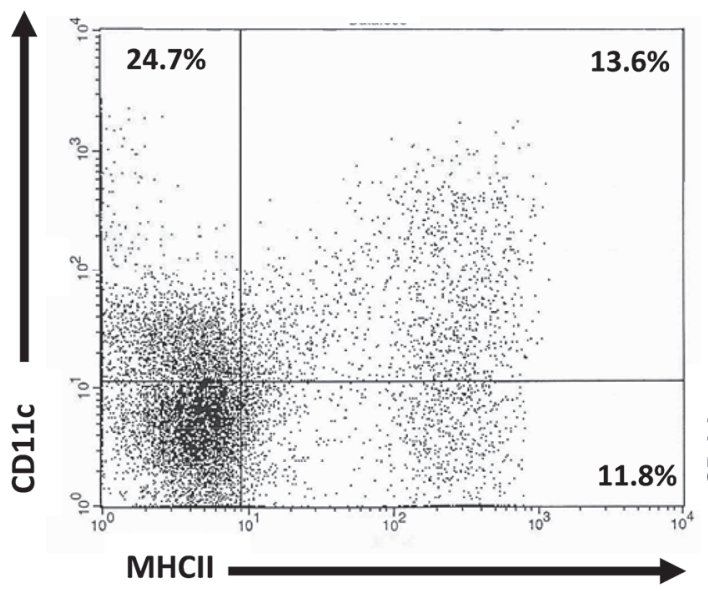

B)

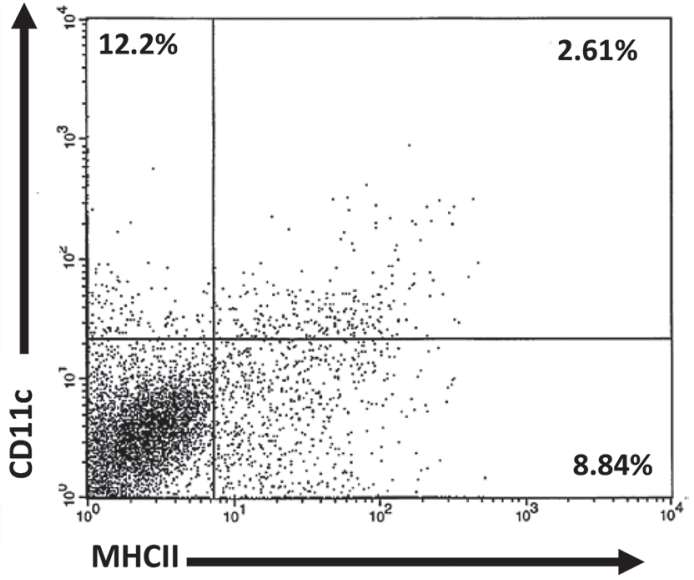

C)

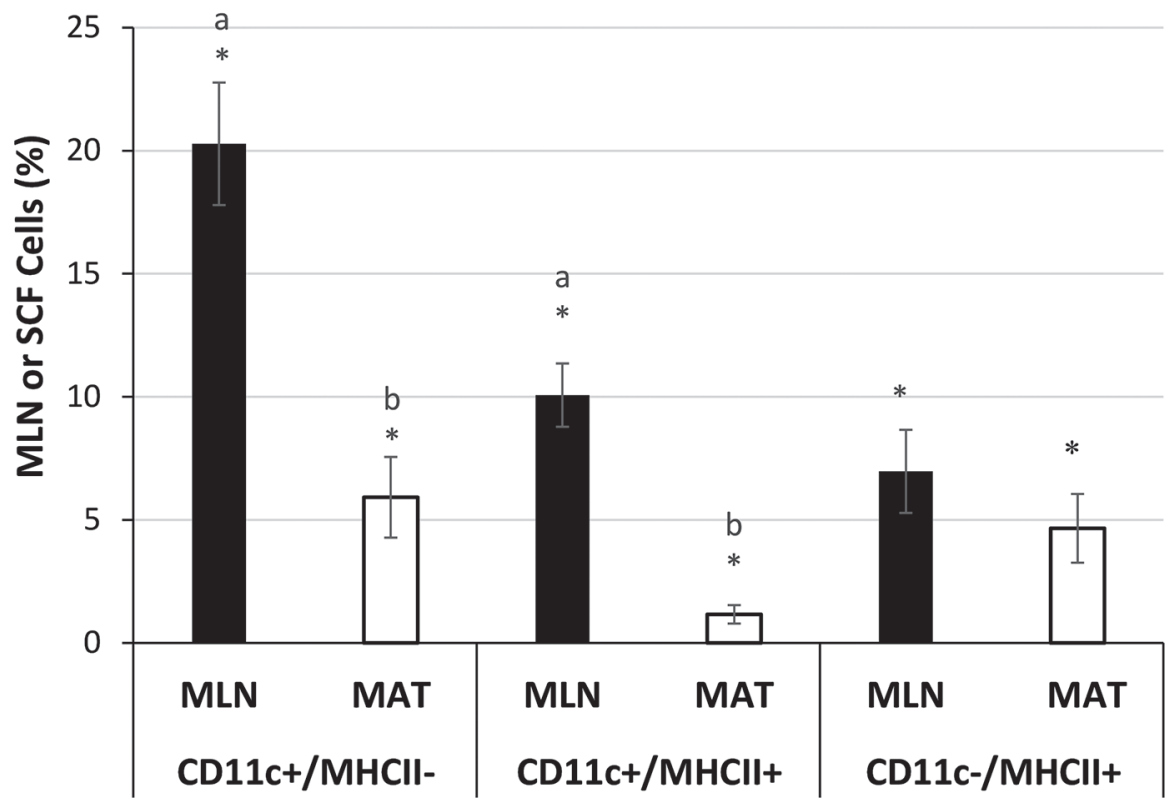

Figure 4. Representative fluorescence-activated cell sorting plots of cluster of differentiation (CD)11c and major histocompatibility complex class II (MHCII) co-expression in the mesenteric lymph node (MLN; A) and mesenteric adipose tissue (MAT) stromal cell fraction (SCF; B) and percent of cells positive for CD11c, for CD11c and MHCII, or for MHCII in the MLN and MAT SCF ( $\mathrm{n}=4$; C). Data are expressed as mean \pm SEM. Means with different letters $(\mathrm{a}, \mathrm{b})$ within staining group differ $(P \leq 0.05)$ and means with $*$ differ from background staining $(P \leq 0.05)$. 
A)

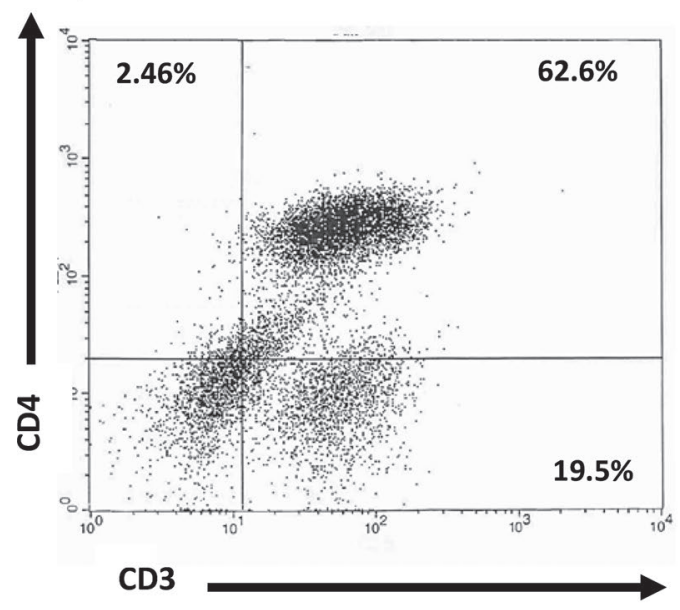

B)

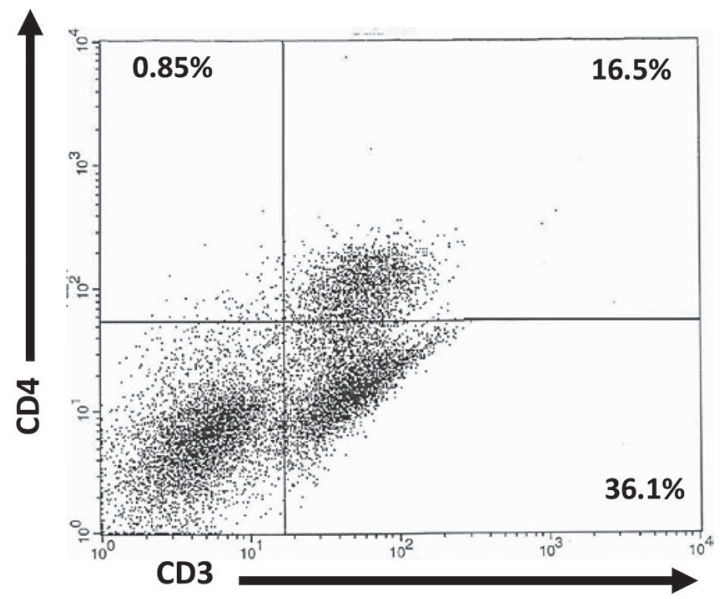

C)

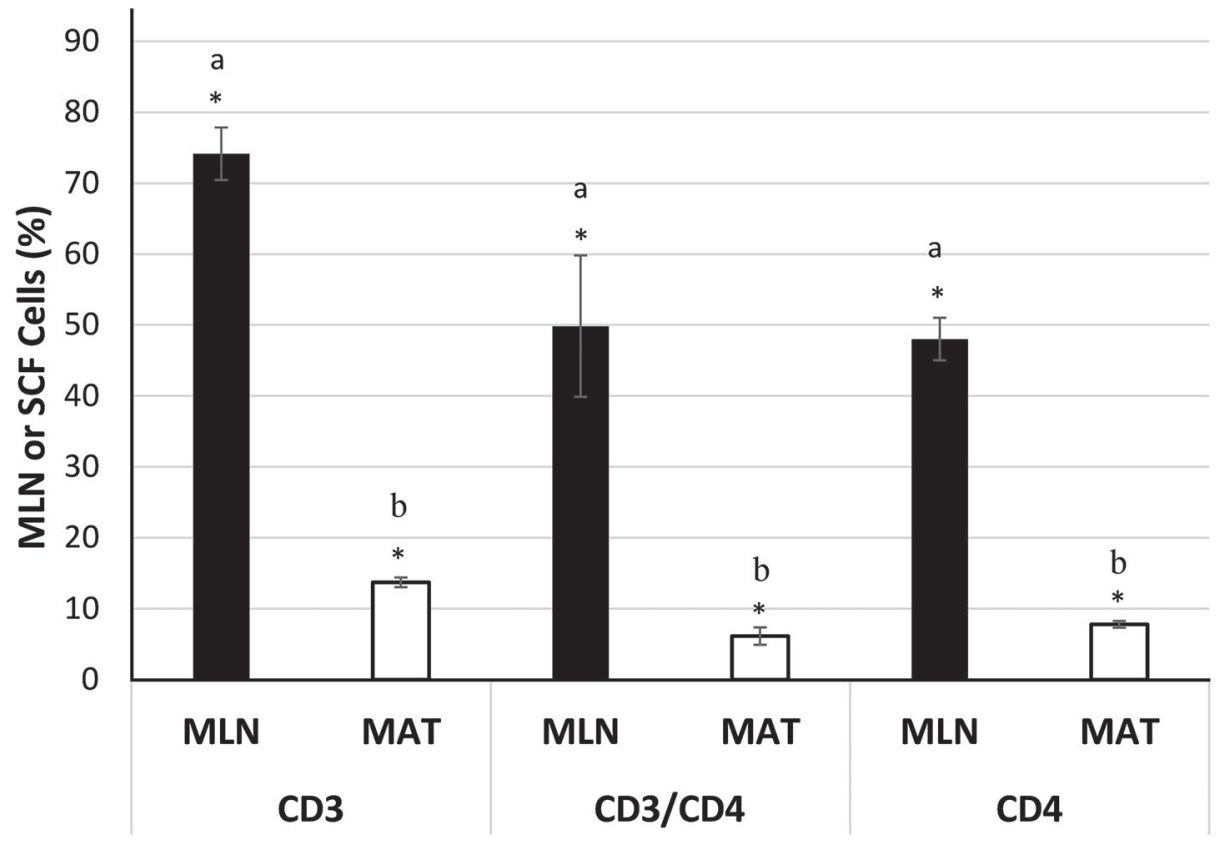

Figure 5. Representative fluorescence-activated cell sorting plots of cluster of differentiation (CD) 4 and CD3 co-expression in the mesenteric lymph node (MLN; A) and mesenteric adipose tissue (MAT) stromal cell fraction (SCF; B) and percent of cells positive for CD3, for CD3 and $\mathrm{CD} 4$, or for CD4 in the MLN and MAT SCF $(\mathrm{n}=5$; C). Data are expressed as mean \pm SEM. Means with different letters $(\mathrm{a}, \mathrm{b})$ within staining group differ $(P \leq 0.05)$ and means with $*$ differ from background staining $(P \leq 0.05)$.

greater than background $(P \geq 0.05)$. Analysis by FACS revealed that $6.65 \pm 0.74 \%$ of the MLN cell population consisted of $\gamma \delta^{+}$lymphocytes, whereas $3.91 \pm 0.43 \%$ of the lymphocyte pool in the MAT SCF were $\gamma \delta^{+} \mathrm{T}$ lymphocytes (Figure 7). Because subpopulations of FoxP $3^{+}$and FoxP $3^{-} \gamma \delta^{+}$regulatory lymphocytes have been described, we also assessed FoxP3 expression in $\gamma \delta$ cells from MAT SCF and MLN. The size of the $\gamma \delta^{+} \mathrm{FoxP}^{+}$double-positive lymphocyte subpopulation was $0.84 \pm 0.33 \%$ in MLN and $0.00 \pm 0.07 \%$ in MAT
SCF (Figure 7). The amount of $\gamma \delta^{+} \mathrm{FoxP}^{+}$expression in the MLN but not the MAT SCF was greater than background $(P \leq 0.05)$. Thus, a small subpopulation of $\gamma \delta^{+} \mathrm{FoxP}^{+}$lymphocytes existed in the MLN.

The CD11c specificities were not limited to the $\mathrm{MHCII}^{+}$myeloid cell population in the MLN. This $\beta 2$ integrin was also co-expressed with CD3 on $10.61 \pm$ $0.62 \%$ of the MLN cells but only $0.19 \pm 0.18 \%$ of the MAT SCF (Figure 8). The level of double-positive cells in the MAT SCF was not above background $(P>0.05)$. 


\section{DISCUSSION}

The present investigation established that resident immune elements in MAT tissues and MLN of lean, lactating dairy cows consist of subpopulations of myeloid and lymphoid anti-inflammatory phenotypes that counterbalance proinflammatory components of the immune response.

Expression of CD11b, CD11c, CD172a, and MHCII in subpopulations of the MAT depot and MLN denotes the presence of resident tissue macrophages and dendritic cells (Miyazawa et al., 2006; González-Cano et al., 2014). The CD11c protein enables monocyte trafficking (Ley et al., 2007) into adipose tissues to provide sentinel, scavenger, and reparative functions sustaining tissue integrity. Populations of anti-inflammatory macrophages expressing CD206, CD301, and Arg1 in visceral bovine adipose depots (Contreras et al., 2015, 2016) are subpopulations of the $\mathrm{CD}_{11 \mathrm{~b}^{+}} \mathrm{CD} 1 \mathrm{c}^{+}$cells described herein. We note that CD11c is expressed on
A)

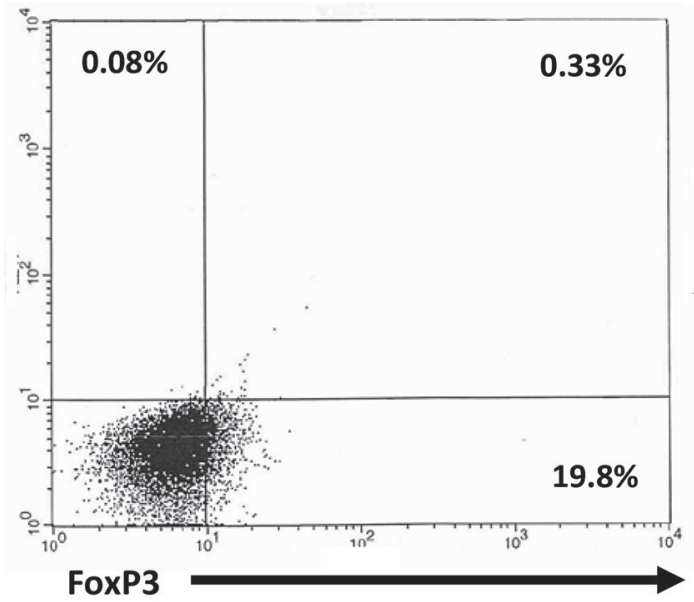

B)

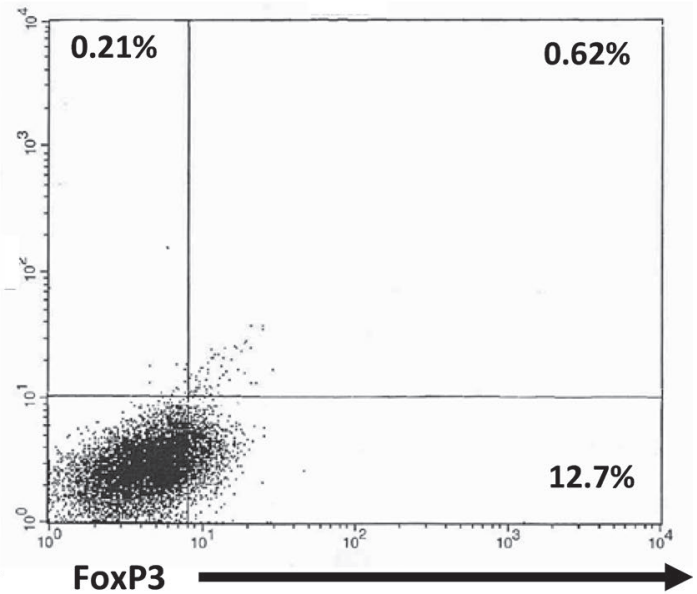

C)

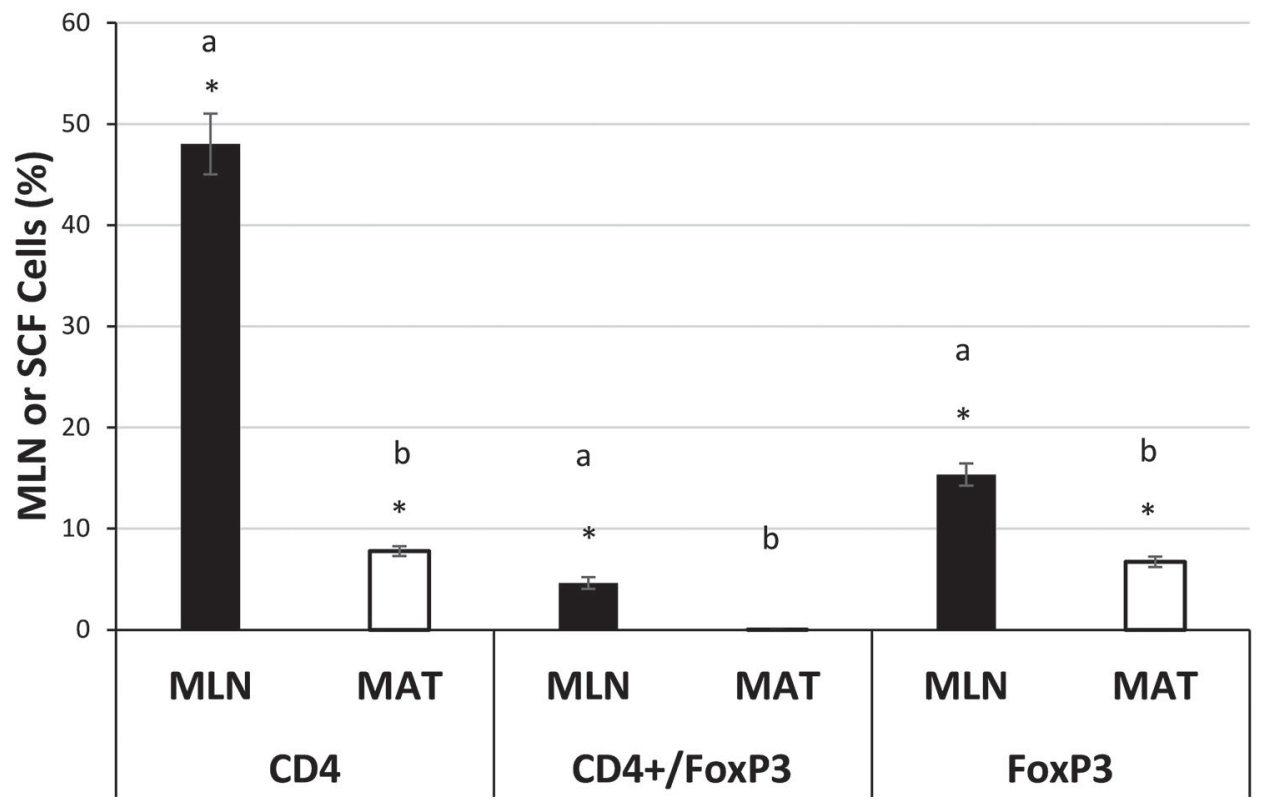

Figure 6. Representative fluorescence-activated cell sorting plot of FoxP3 expression in the mesenteric lymph node (MLN; A) and mesenteric adipose tissue (MAT) stromal cell fraction (SCF; B) and percent of cells positive for cluster of differentiation (CD)4, for FoxP3 and CD4, or for FoxP3 in the MLN $(\mathrm{n}=8)$ and MAT SCF $(\mathrm{n}=7 ; \mathrm{C})$. Data are expressed as mean \pm SEM. Means with different letters (a, b) within staining group differ $(P \leq 0.05)$ and means with $*$ differ from background staining $(P \leq 0.05)$. 


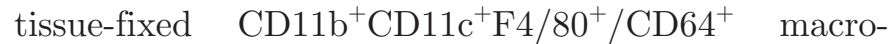
phages and peripheral blood monocytes (Hope et al., 2000; Tamoutounour et al., 2012; Cho et al., 2016) but is also constitutively expressed across all lineages of dendritic cells (Steinman et al., 1979; Nussenzweig et al., 1981; Metlay et al., 1990; Merad et al., 2013). This distinction is important because macrophages focus on tissue integrity and remodeling, whereas dendritic cells modulate immune responses in adipose depots and the gastrointestinal tract.

Phenotypic diversity inherent within myeloid populations of either tissue was exemplified in populations co-expressing MHCII with CD11c and CD11b with
CD172a. The $\mathrm{CD} 11 \mathrm{~b}^{+}$and $\mathrm{CD}^{-} 1 \mathrm{~b}^{-}$populations both expressed CD172a, whereas other $\mathrm{CD}_{11 b^{+}}$subpopulations lacked CD172a expression. The size of the CD172a $\mathrm{a}^{+}$cell population in the adipose SCF of lean cows is consistent with those reported in nonlactating, healthy Holstein cows and lactating cows with displaced abomasum (Contreras et al., 2015, 2016). The CD11b ${ }^{\text {high }}$, CD172a ${ }^{\text {high }}$ phenotypes occur in macrophages; CD11b ${ }^{-}$CD172a ${ }^{\text {high }}$ and CD11b ${ }^{\text {low }}$ CD172a $\mathrm{a}^{\text {high }}$ phenotypes appear in immature and mature dendritic cells (McKeever et al., 1991; Miyazawa et al., 2006; Seo et al., 2009a) and is consistent with earlier work showing that CD172a-expressing cells support clonal
A)

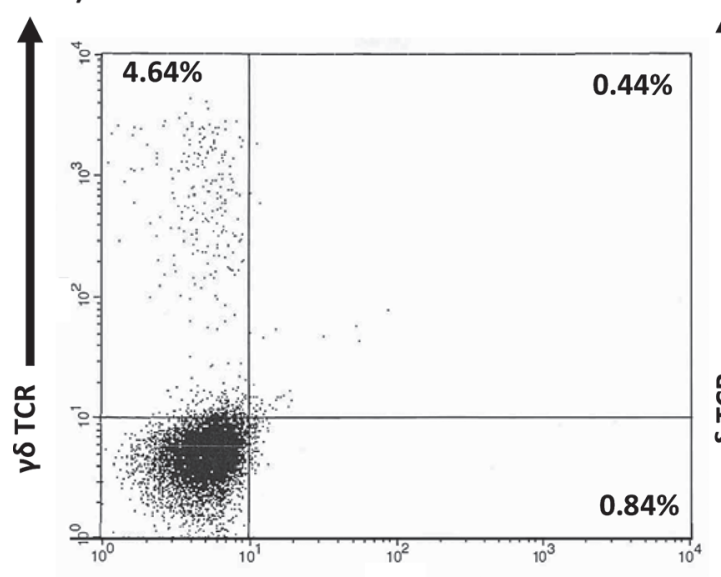

B)

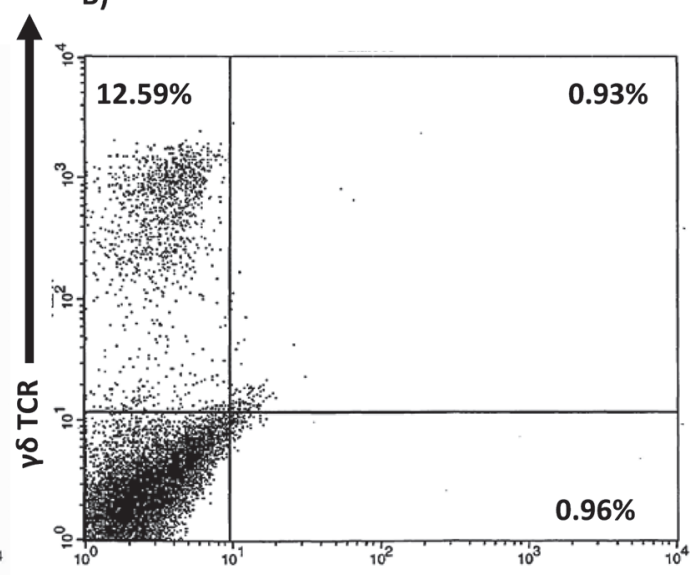

a

C)

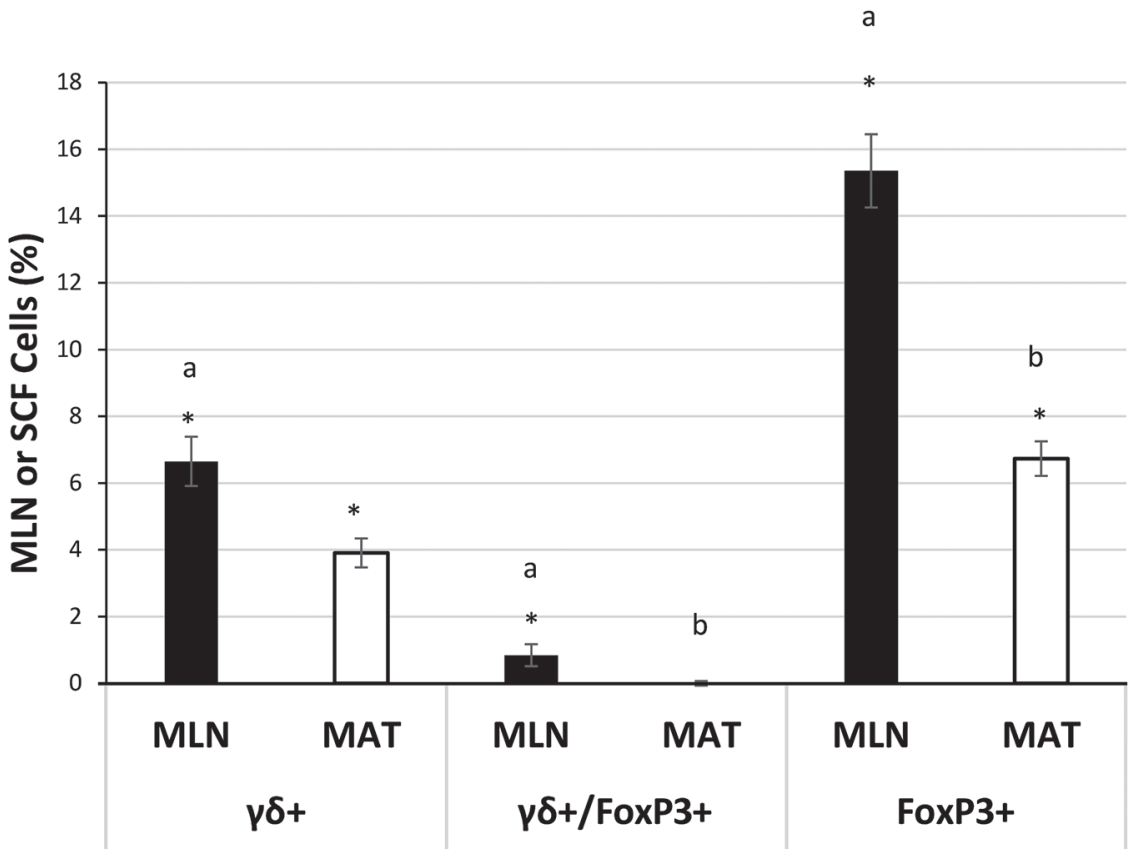

Figure 7. Representative fluorescence-activated cell sorting plot of $\gamma \delta$ expression in the mesenteric lymph node (MLN; A) and mesenteric adipose tissue (MAT) stromal cell fraction (SCF; B) and percent of cells positive for $\gamma \delta$, for $\gamma \delta$ and FoxP3, or for FoxP3 in the MLN (n $=14$ ) and MAT SCF $(\mathrm{n}=14 ; \mathrm{C})$. Data are expressed as mean \pm SEM. Means with different letters $(\mathrm{a}, \mathrm{b})$ within staining group differ $(P \leq 0.05)$ and means with $*$ differ from background staining $(P \leq 0.05)$ 
A)

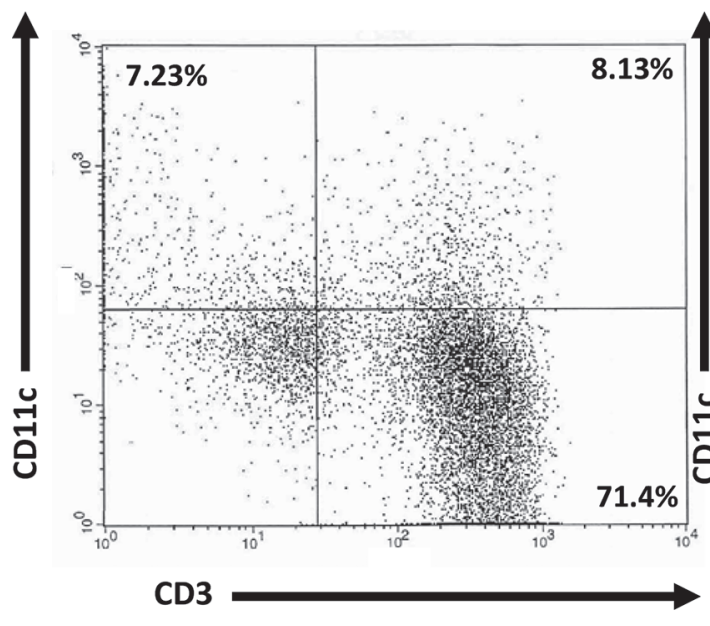

B)

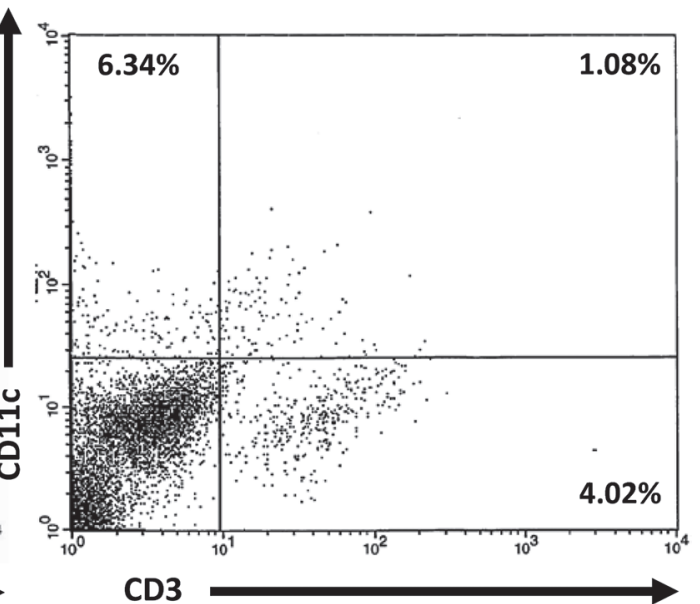

C)

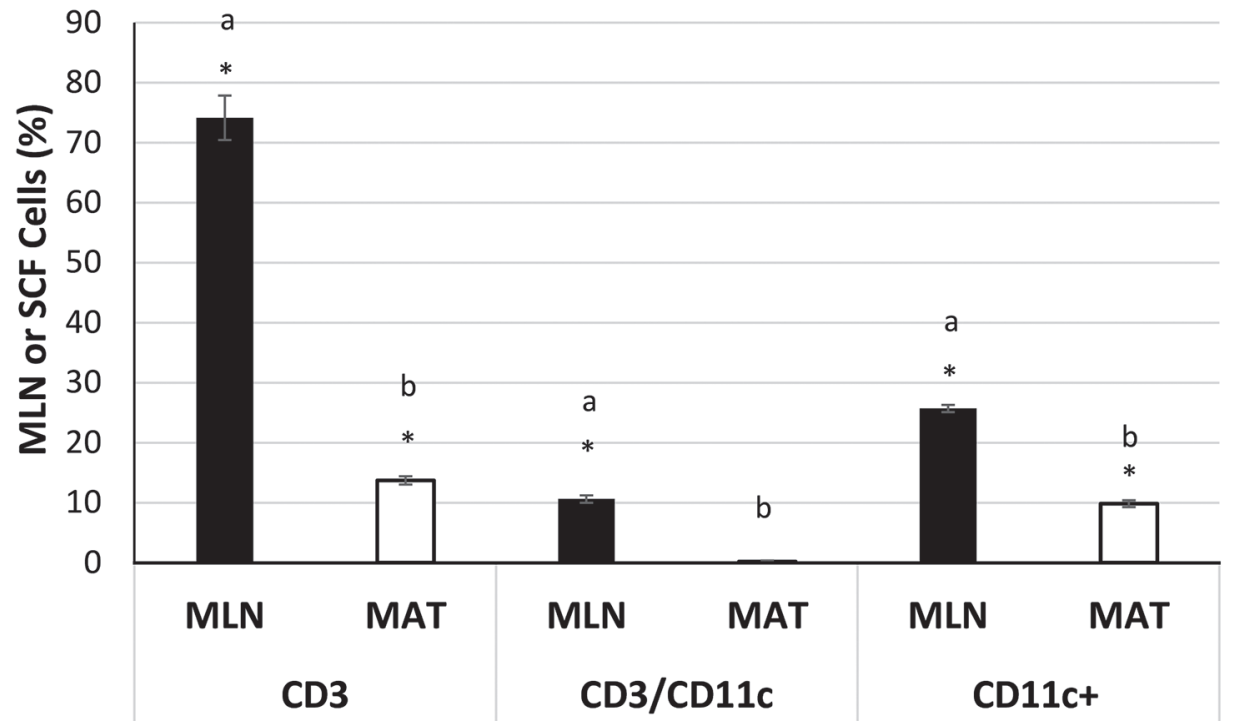

Figure 8. Representative fluorescence-activated cell sorting plots of cluster of differentiation (CD)11c and CD3 co-expression in the mesenteric lymph node (MLN; A) and mesenteric adipose tissue (MAT) stromal cell fraction (SCF; B) and percent of cells positive for CD3, for CD3 and CD11c, or for CD11c in the MLN and MAT SCF $(\mathrm{n}=4 ; \mathrm{C})$. Data are expressed as mean \pm SEM. Means with different letters $(\mathrm{a}$, b) within staining group differ $(P \leq 0.05)$ and means with $*$ differ from background staining $(P \leq 0.05)$.

expansion of $\mathrm{T}$ helper (Th)1/Th2 effector (Brooke et al., 1998) and $\gamma \delta^{+}$FoxP $^{-}$regulatory lymphocytes (Guzman et al., 2014). Clonal expansion of Th2 and regulatory $\gamma \delta$ lymphocytes supports regulatory/antiinflammatory functions in the adipose and oral tolerance in the intestine.

The CD172a ${ }^{-}$and CD172a ${ }^{\text {high }}$ cells in the MLN stem from migrating lamina propria-derived dendritic cells that have sampled intestinal microbiome (Turnbull et al., 2005; Jang et al., 2006) and trafficked in bovine afferent lymph (Howard et al., 1997; Gliddon and Howard, 2002; Stephens et al., 2003) to the MLN (Liu et al., 1998; Cerovic et al., 2013).
Subpopulations of $\mathrm{CD}_{11 \mathrm{c}^{+}}$and $\mathrm{CD}_{11 \mathrm{c}^{-}}$cells coexpressed or failed to express MHCII, consistent with phenotypes of steady-state, tissue-fixed dendritic cells and macrophages. Pools of $\mathrm{CD} 11 \mathrm{c}^{+} \mathrm{MHCII}^{+}$circulating monocytes, dendritic cells, bone marrow-derived stem cells, and migrating dendritic cells (Howard et al., 1997; González-Cano et al., 2014; Cho et al., 2016) sustain these populations of tissue-fixed $\mathrm{CD}_{11 \mathrm{c}^{+}} \mathrm{MHCII}^{+}$ CD172a $\mathrm{a}^{+}$and $\mathrm{CD} 11 \mathrm{~b}^{+}$macrophages and dendritic cells. In the steady state, activated dendritic cells and macrophages trafficking into the MLN and MAT dampen CD11c and upregulate MHCII expression (Hope et al., 2000; Seo et al., 2009a) during maturation into antigen- 
presenting cells. Subpopulations of MHCII ${ }^{\text {high }}$ CD11 $\mathrm{c}^{\text {high }}$ found in the MLN likely arise from $\mathrm{MHCII}^{\text {high }} \mathrm{CD} 11 \mathrm{~b}^{\text {high }}$ CD11c ${ }^{\text {high }}$ dendritic cells trafficking from the intestinal mucosa via afferent mesenteric lymphatics (Gliddon and Howard, 2002; Turnbull et al., 2005; Worbs et al., 2006). Dendritic cells and macrophages in the murine intestinal lamina propria continuously pass pseudopods between mucosal epithelium to sample the microbiome (Farache et al., 2013). The cells exit the mucosa and traffic, via the mesenteric lymphatics, to the MLN. This pattern of dendritic cell trafficking underpins anatomic and functional relationships between $\mathrm{CD}_{11 \mathrm{c}^{+}} \mathrm{MHCII}^{+}$ dendritic cells in afferent lymphatic vessels (Howard et al., 1997), the cells described herein in the MLN, and those in the intestine (Fries et al., 2011; GonzálezCano et al., 2014). Functional characterization of these phenotypes would begin to define how regulatory and proinflammatory phenotypes orchestrate immune homeostasis in adipose (Kotas and Medzhitov, 2015; Panduro et al., 2016) and intestine tissues (Brooke et al., 1998; Turnbull et al., 2005; Bekiaris et al., 2014).

The inability to detect CD209 in the MLN and MAT $\mathrm{SCF}$ is concordant with trace amounts of expression $(0.74 \%)$ in bovine peripheral blood dendritic cells/ monocytes (González-Cano et al., 2014; Park et al., $2015,2016)$ but inconsistent with reports of expression in immature and mature dendritic cells from lymphoid tissues (Cheong et al., 2010; Park et al., 2016). A multifunctional integrin, CD209 also binds fucose or mannose residues (Feinberg et al., 2001; van Liempt et al., 2006), triggering signals that augment (mannose) IL-12 and IL-6 or suppress (fucose) proinflammatory cytokine secretion of dendritic cells (Gringhuis et al., 2009). The functional significance of the apparent absence of expression in mesenteric tissues is unclear.

The MLN and MAT SCF cell populations contained considerable numbers of $\mathrm{CD}^{+}$lymphocytes. Antigen specificity in the MLN ranges across gut pathogens, dietary antigens, and commensal microbial antigens. Antigen specificity in the MAT SCF remains an enigma. The $\mathrm{CD}^{+}{ }^{+} \mathrm{CD} 4^{+}$phenotypes in adipose tissue likely consist of a mix of Th1, Th2, Th17, and Treg effector lymphocytes dominated by regulatory and Th2 functions (Caspar-Bauguil et al., 2005; Winer et al., 2009). In lean adipose tissues, MHCII-mediated antigen presentation drives Th2 production of IL-4 and IL-13 (Winer et al., 2009) and Treg production of IL-10. Collectively, these cytokines sustain anti-inflammatory macrophage functions in bovine adipose depots (Contreras et al., 2015, 2016).

The percentage of bovine $\mathrm{CD} 3{ }^{+} \mathrm{CD} 4^{+}$and $\mathrm{CD} 3^{+} \mathrm{CD} 8^{+}$ cells in the MLN supports earlier reports (Sopp and Howard, 2001). The size of the $\mathrm{CD} 3^{+} \mathrm{CD} 4^{+}$lymphocyte pool in the steady-state bovine MAT SCF supports results from other reports (Caspar-Bauguil et al., 2005; Nishimura et al., 2009) but was greater than that reported by Feuerer et al. (2009) in mice. The absence of $\mathrm{CD}^{+}{ }^{+} \mathrm{CD} 8^{+}$cells in the MAT SCF is consistent with anti-inflammatory functions enabling physiologic rather than inflammatory control of metabolic homeostasis in lean MAT SCF (Caspar-Bauguil et al., 2005; Feuerer et al., 2009; Nishimura et al., 2009).

With one exception (Gerner et al., 2010), the size of the $\mathrm{CD}^{+}{ }^{+} \mathrm{FoxP}^{+}$MLN subpopulation is consistent with pool sizes in peripheral blood (Hoek et al., 2009; Suzuki et al., 2013). The size of the FoxP3 ${ }^{+}$MLN subpopulation was 5 -fold greater than estimates generated by in situ staining (Roussey et al., 2016). This discrepancy likely reflects differences in experimental methodology, genetics, diet, or housing environment. The relatively large size of the FoxP $3^{+}$regulatory $\mathrm{T}$ lymphocyte population in the MLN implies that a state of tolerance dominates mucosal immune homeostasis.

FoxP $3^{+}$subpopulations in the bovine MLN are likely generated by commensal bacterial antigens (Lathrop et al., 2011; Cebula et al., 2013) restricted off the CD11c ${ }^{+}$ $\mathrm{MHCII}^{+}, \mathrm{CD}_{11} \mathrm{c}^{-} \mathrm{MHCII}^{+}$, and $\mathrm{CD}_{11} \mathrm{~b}^{+}$and $\mathrm{CD} 11 \mathrm{~b}^{-}$ cells (Coombes et al., 2007; Welty et al., 2013; Loschko et al., 2016) described herein. This subset of FoxP3 lymphocytes initiates and sustains the oral mucosal tolerance (Worbs et al., 2006; Hadis et al., 2011) that blocks inflammatory bowel disease (Mucida et al., 2005; Hadis et al., 2011). Existence of this FoxP3 subpopulation in the bovine MLN raises an important question about its role in sustaining enteric mucosal tolerance during diet-induced shifts in commensal bacterial populations in the intestine.

The size of the subpopulation of FoxP $3^{+}$cells in lean bovine MAT SCF is consistent with reports in murine visceral adipose tissues (Deiuliis et al., 2011; Cipolletta et al., 2015). The relative proportion of resident adipose lymphocytes existing as FoxP3 ${ }^{+}$lymphocytes remains to be formally established but data reported herein suggest that 40 to $50 \%$ (6.73\% FoxP3 ${ }^{+}$cells, $13.72 \pm$ $0.69 \% \mathrm{CD}^{+}$cells) of the $\mathrm{CD}^{+}$lymphocytes are regulatory. We propose that the $\mathrm{MHCII}^{+} \mathrm{CD}_{11 \mathrm{c}^{+}}$macrophage/dendritic cell populations found in MAT SCF and MLN are the antigen-restricting cells supporting Treg clonal expansion (Feuerer et al., 2009; Cipolletta et al., 2015; Kolodin et al., 2015). The relative size of the Treg population implies that regulatory functions dominate immune homeostasis in lean fat and provides the quintessential anti-inflammatory/regulatory environment that is the cornerstone of physiologic rather than inflammatory control of metabolic variables in the adipose depot (Panduro et al., 2016).

The size of the MLN $\gamma \delta^{+}$lymphocyte population was larger than earlier estimates for bovines (Wilson et al., 
1996; Sopp and Howard, 2001). The size of the $\gamma \delta^{+}$ lymphocyte population in the MAT SCF was comparable to those of lean murine adipose (Caspar-Bauguil et al., 2005; Mehta et al., 2015). The function(s) of these tissue-fixed lymphocytes in bovine MAT and MLN remains completely undefined. Elasticity in effector cell functions render $\gamma \delta$ lymphocytes producers of pro- and anti-inflammatory cytokines (IFN $\gamma$, IL-6, IL-17, IL-4, IL-13, transforming growth factor- $\beta$, IL-10, and granulocyte-macrophage colony-stimulating factor; Sopp and Howard, 2001; Bonneville et al., 2010; Guzman et al., 2012). In lean murine fat, a relatively small proportion of $\gamma \delta \mathrm{T}$ lymphocytes exist as an MCP-1 $1^{+}$ (monocyte chemoattractant protein-1), IFN $\gamma^{+}, \mathrm{IL}-6^{+}$, IL- $17^{+}$, or $\mathrm{TNF}-\alpha^{+}$(tumor necrosis factor- $\alpha$ ) proinflammatory phenotype (Zuniga et al., 2010; Mehta et al., 2015; Kohlgruber et al., 2018). Subpopulations of adipose IL- $17^{+} \gamma \delta \mathrm{T}$ cells clonally expand Treg numbers by orchestrating IL-33 production from adipose stromal cells (Kolodin et al., 2015; Kohlgruber et al., 2018). Expanded populations of Treg favor anti-inflammatory polarization (Contreras et al., 2015, 2016) of CD11c ${ }^{+}$ $\mathrm{CD}_{11} \mathrm{~b}^{+} \mathrm{MHCII}^{+} \mathrm{CD} 172 \mathrm{a}^{+}$macrophages described herein for lean adipose tissues. Obesity polarizes resident $\gamma \delta \mathrm{T}$ cell pools (Caspar-Bauguil et al., 2005; Mehta et al., 2015) into producers of proinflammatory TNF- $\alpha$, IL-17, and MCP-1 (Zuniga et al., 2010;

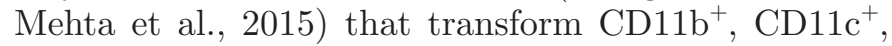
$\mathrm{MHCII}^{+}, \mathrm{CD} 172 \mathrm{a}^{+}$macrophages into proinflammatory phenotypes (Eberl and Moser, 2009; Eberl et al., 2009; Contreras et al., 2015).

The MLN contained a minor population of FoxP $3^{+} \gamma \delta^{+}$ regulatory lymphocytes that support gastrointestinal tolerance (Casetti et al., 2009). The absence of FoxP $3^{+} \gamma \delta \mathrm{T}$ cells in the MAT SCF, however, does not rule against regulatory functions in MAT SCF $\gamma \delta$ subpopulations (Seo et al., 2007, 2009b; Hoek et al., 2009) because some bovine FoxP $3^{-} \gamma \delta$ lymphocytes mediate transforming growth factor- $\beta$ and IL-10 regulatory functions (Hoek et al., 2009; Guzman et al., 2014). Functional linkage of this phenotype to the tissue-fixed $\gamma \delta$ lymphocytes described herein could establish regulatory paradigms of immune homeostasis enabling physiologic rather than inflammatory controller adjustments of metabolic set points and tolerance in the fat and gastrointestinal tract, respectively (Rhodes et al., 2001; Hoek et al., 2009; Guzman et al., 2014).

Steady-state bovine MLN but not MAT harbor relatively large numbers of $\mathrm{CD}^{+} \mathrm{CD}^{\mathrm{C}} 1 \mathrm{c}^{+}$lymphocytes. Expression of CD11c occurs on CD2 ${ }^{+}$lymphocytes (Hall et al., 1993; Hope et al., 2000), invariant chain natural killer cells (iNK lymphocytes; Luo et al., 2007), $\gamma \delta$ lymphocytes (Hall et al., 1993), activated $\mathrm{CD} 8^{+}$regulatory lymphocytes (Hope et al., 2000; Seo et al., 2007;
Vinay et al., 2009), and innate lymphoid cells (type 1, 2 , and 3). Their function in bovines deserves investigation because, in other species, innate lymphocytes regulate homeostasis in mucosal immune responses and support mucus (Oeser et al., 2015) and antimicrobial peptide secretion (Sonnenberg et al., 2012) by mucosal epithelial cells.

In summary, immune cell phenotypes described in the MAT and MLN provide circumstantial evidence that immune elements of myeloid and lymphoid origin provide regulatory environments that enable physiologic, rather than inflammatory, controls to set variables of metabolic activity and mucosal tolerance (Lumeng et al., 2007; Straus and Glass, 2007; Van Dyken and Locksley, 2013). The consistent yield of myeloid and lymphoid elements from MAT digests led us to conclude that immune elements can reside in all MAT, in contrast to results reported by Akter et al. (2012). The state of the regulatory environment could explain conflicting conclusions about adipose infiltrates of myeloid cells drawn from the immunohistocytochemical studies performed by Akter et al. (2012) and the immunohistochemical and flow cytometry studies performed by Contreras et al. (2015, 2016). The amount of regulatory activity in MAT could explain results supporting (Contreras et al., 2015; Vailati-Riboni et al., 2016, 2017) or refuting (Ji et al., 2012, 2014; Mann et al., 2015) proinflammatory gene expression in lipid-filled adipose tissues. Regulatory immune phenotype(s) in the MLN could generate the anti-inflammatory environments supporting the mucosal permeability barrier integrity that prevents trans-mucosal translocation of commensal bacterial elements triggering adipose inflammation (Cani et al., $2007,2008)$. Although the majority of immune signals from the intestinal mucosa influence cellular structure and function in the MLN, experimental evidence shows that the phenotypic structure of the MLN is also transformed by signals arising from the mesenteric adipose depot (Magnuson et al., 2017). Even within the limited realm of available reagents, results from this study set the foundation upon which the functional phenotypes of regulatory/anti-inflammatory elements in fat and the intestine can be explored. Reining in unrestrained proinflammatory immune activity in the intestinal mucosa associated with dietary shifts could support a more seamless metabolic transition through energy, ration, and production stressors of the postpartum period.

\section{ACKNOWLEDGMENTS}

The authors thank Burlington Beef (Monroeville, NJ) for their time, commitment, and generous coopera- 
tion with tissue sample collection, animal inspection, and body condition scoring of abattoir animals.

\section{REFERENCES}

Akter, S. H., S. Haussler, D. Germeroth, D. von Soosten, S. Danicke, K. H. Sudekum, and H. Sauerwein. 2012. Immunohistochemical characterization of phagocytic immune cell infiltrates into different adipose tissue depots of dairy cows during early lactation. J. Dairy Sci. 95:3032-3044.

Akter, S. H., S. Haussler, S. Danicke, U. Muller, D. von Soosten, J. Rehage, and H. Sauerwein. 2011. Physiological and conjugated linoleic acid-induced changes of adipocyte size in different fat depots of dairy cows during early lactation. J. Dairy Sci. 94:2871-2882.

Atarashi, K., T. Tanoue, T. Shima, A. Imaka, T. Kuwahara, Y. Momose, G. Cheng, S. Yamasaki, T. Saito, Y. Ohba, T. Tanaguchi, K. Takeda, S. Hori, I. I. Ivanov, Y. Umesaki, K. Itoh, and K. Honda. 2011. Induction of colonic regulatory $\mathrm{T}$ cell by indigenous Clostridium species. Science 331:337-341.

Bekiaris, V., E. K. Perrson, and W. W. Agace. 2014. Intestine dendritic cells in regulation of mucosal immunity. Immunol. Rev. 260:86-101.

Bonneville, M., R. L. O'Brien, and W. K. Born. 2010. $\gamma \delta$ T cell effector functions: A blend of innate programming and acquired plasticity. Nat. Rev. Immunol. 10:467-478.

Brooke, G. P., K. R. Parsons, and C. J. Howard. 1998. Cloning of two members of the SIRP alpha family pf protein tyrosine phosphatase binding proteins in cattle that are expressed on monocytes and a subpopulation of dendritic cells and which mediate binding to CD4 T cells. Eur. J. Immunol. 28:1-11.

Cani, P. D., J. Amar, M. A. Iglesias, M. Poggi, C. Knauf, D. Bastelica, A. M. Neyrinck, F. Fava, K. M. Tuohy, C. Chabo, A. Waget, E. Delmée, B. Cousin, T. Sulpice, B. Chamontin, J. Ferrières, J. F. Tanti, G. R. Gibson, L. Casteilla, N. M. Delzenne, M. C. Alessi, and R. Burcelin. 2007. Metabolic endotoxemia initiates obesity and insulin resistance. Diabetes 56:1761-1772.

Cani, P. D., R. Bibiloni, C. Knauf, A. Waget, A. M. Neyrinck, N. M. Delzenne, and R. Bercelin. 2008. Changes in gut microbiota control metabolic endotoxemia-ionduced inflammation in high fat diet induced obesity and diabetes in mice. Diabetes 57:1470-1481.

Casetti, R., C. Agrati, M. Wallace, A. Sacchi, F. Martini, A. Marlino, A. Rinaldi, and M. Malkovsky. 2009. Cutting edge: TGF- $\beta 1$ and IL-15 induce FOXP3 $+\gamma \delta$ regulatory $\mathrm{T}$ cells in the presence of antigen stimulation. J. Immunol. 183:3574-3577.

Caspar-Bauguil, S., B. Cousin, A. Galinier, C. Segafredo, M. Nibbelink, M. Andre, L. Casteilla, and L. Penicaud. 2005. Adipose tissues as an ancestral immune organ: Site-specific changes in obesity. FEBS Lett. 579:3487-3492.

Cebula, A., M. Seweryn, G. A. Rempala, S. S. Pabla, R. A. McIndoe, T. L. Denning, L. Bry, P. Kraj, P. Kisielow, and L. Ignatowicz. 2013. Thymus-derived regulatory T cells control tolerance to commensal microbiota. Nature 497:258-262.

Cerovic, V., S. A. Houston, C. L. Scott, A. Aumeunier, U. Yrlid, A. M. Mowat, and S. W. S. A. Milling. 2013. Intestinal CD103(-) dendritic cells migrate in lymph and prime effector T cells. Mucosal Immunol. 6:104-113.

Cheong, C., I. Matos, J. Choi, D. Bhavani, E. S. Dandamudi, M. P. Longhi, K. L. Jeffrey, R. M. Anthony, C. Kluger, G. Nchinda, H. Koh, A. Rodriguez, J. Idoyaga, M. Pack, K. Velinzon, C. G. Park, and R. M. Steinman. 2010. Microbial stimulation fully differentiates monocytes to DC-SIGN CD209+ dendritic cells for immune T cell areas. Cell 143:416-429.

Cho, K. W., B. F. Zamarron, L. A. Muir, K. Singer, C. E. Porsche, J. B. DelProposto, L. Geletka, K. A. Meyer, R. W. O'Rourke, and C. N. Lumeng. 2016. Adipose tissue dendritic cells are independent contributors to obesity-induced inflammation and insulin resistance. J. Immunol. 197:3650-3661.

Cipolletta, D., P. Cohen, B. M. Speigelman, C. Benoist, and D. Mathis. 2015. Appearance and disappearance of the mRNA sig- nature characteristics of Treg cells in visceral adipose tissue: Age, diet, and PPAR $\gamma$ effects. Proc. Natl. Acad. Sci. USA 112:482-487.

Contreras, G. A., G. E. Kabara, J. Brester, L. Neuder, and M. Kiupel. 2015. Macrophage infiltration in the omental and subcutaneous adipose tissues of dairy cows with displaced abomasum. J. Dairy Sci. 98:6176-6187.

Contreras, G. A., K. Thelen, S. E. Schmidt, C. Strieder-Barboza, C. L. Preseault, W. Raphael, M. Kiupel, J. Caron, and A. L. Lock. 2016. Adipose tissue remodeling in late-lactation dairy cows during feed-restriction-induced negative energy balance. J. Dairy Sci. 99:10009-10021.

Coombes, J. L., K. R. Siddiqui, C. V. Arancibia-Carcamo, J. Hall, C. M. Sun, Y. BelKaid, and F. Powrie. 2007. A functionally specialized population of mucosal CD103+ DCs induces Foxp3+ regulatory $\mathrm{T}$ cells via a TGF-beta and retinoic acid-dependent mechanism. J. Exp. Med. 204:1757-1764.

Dann, H. M., N. B. Litherland, J. P. Underwood, M. Bionaz, A. D'Angelo, J. W. McFadden, and J. K. Drakley. 2006. Diets during far-off and close-up dry periods affect periparturient metabolism and lactation in multiparous cows. J. Dairy Sci. 89:3563-3577.

Deiuliis, J., Z. Shah, N. Shah, B. Needleman, D. Mikami, V. Narula, K. Perry, J. Hazey, T. Kampfrath, M. Kollengode, Q. Sun, A. R. Sotaskar, C. Lumeng, and S. Moffatt-Bruce. 2011. Visceral adipose inflammation in obesity is associated with critical alterations in tregulatory cell numbers. PLoS One 6:e16376. https://doi.org/10 .1371 /journal.pone.0016376.

Depreester, E., J. DeKoster, M. Van Poucke, M. Hostens, W. Van den Broeck, L. Peelman, G. A. Contreras, and G. Opsomer. 2018. Influence of adipocyte size and adipose depot on the number of adipose tissue macrophages and the expression of adipokines in dairy cows at the end of pregnancy. J. Dairy Sci. 101:6542-6555.

Eberl, M., and B. Moser. 2009. Monocytes and gamma delta T cells: Close encounters in microbial infection. Trends Immunol. 30:562568.

Eberl, M., G. W. Roberts, S. Meuter, J. D. Williams, N. Topley, and B. Moser. 2009. A rapid crosstalk of human gammadelta T cells and monocytes drives the acute inflammation in bacterial infections. PLoS Pathog. 5:e1000308.

Farache, J., I. Koren, I. Milo, I. Gurevich, K. W. Kim, E. Zigmond, G. C. Furtado, S. A. Lira, and G. Shakhar. 2013. Luminal bacteria recruit CD103+ dendritic cells into the intestinal epithelium to sample bacterial antigens for presentation. Immunity 38:581-595.

Feinberg, H., D. A. Mitchell, K. Drickamer, and W. I. Weis. 2001 Structural basis for selective recognition of oligosaccharides by DC-SIGN and DC-SIGNR. Science 294:2163-2166.

Ferguson, J. D., D. T. Galligan, and N. Thomsen. 1994. Principal descriptors of body condition score in Holstein cows. J. Dairy Sci. 77:2695-2703.

Feuerer, M., L. Herrero, D. Copaletta, A. Naaz, J. Wong, A. Nayer, J. Les, A. Goldfine, C. Benoist, S. Shoelson, and D. Mathis. 2009. Lean but not obese fat is enriched for a unique population of regulatory $\mathrm{T}$ cells that affect metabolic parameters. Nat. Med. 15:930-939.

Fries, P., Y. I. Popowych, L. Guanle, T. Beskorwayne, A. Potter, L. Babuik, and P. J. Giebel. 2011. Mucosal dendritic cell subpopulations in the small intestine of newborn calves. Dev. Comp. Immunol. 35:1040-1051.

Gerner, W., M. Stadler, S. E. Hammer, D. Klein, and A. Saalmuller. 2010. Sensitive detection of FoxP3 expression in bovine lymphocytes by flow cytometry. Vet. Immunol. Immunopathol. 138:154158.

Gliddon, D. R., and C. J. Howard. 2002. CD26 is expressed on a restricted subpopulation of dendritic cells in vivo. Eur. J. Immunol. 32:1472-1481.

González-Cano, P., N. Arsic, Y. I. Popowych, and P. J. Griebel. 2014 Two functionally distinct myeloid dendritic cell subpopulations are present in bovine blood. Dev. Comp. Immunol. 44:378-388.

Gringhuis, S. I., J. den Dunnen, M. Litjens, M. van der Vlist, and T. B. Geijtenbeek. 2009. Carbohydrate-specific signaling through the DC-SIGN signalosome tailors immunity to Mycobacterium tuberculosis, HIV-1 and Helicobacter pylori. Nat. Immunol. 10:1081-1088. 
Guzman, E., S. Price, H. Paulsom, and J. Hope. 2012. Bovine $\gamma \delta T$ cells: Cells with multiple functions and important roles in immunity. Vet. Immunol. Immunopathol. 148:161-167.

Guzman, E., J. Hope, G. Taylor, A. I. Smith, C. Cubillos-Zapata, and C. Charleston. 2014. Bovine $\gamma \delta \mathrm{T}$ cells are a major regulatory $\mathrm{T}$ cell subset. J. Immunol. 193:208-222.

Hadis, U., B. Wahl, O. Schulz, M. Hardtke-Wolenski, A. Schippers, N. Wagner, W. Muller, T. Sparwasser, R. Forster, and O. Pabst. 2011. Intestinal tolerance requires gut homing and expansion of FoxP3+ REGULATORY T cells in the lamina propria. Immunity 34:237-246.

Hall, G. A., P. Sopp, and C. J. Howard. 1993. An investigation of temporary workshop clusters reacting with cells of the mononuclear phagocytic system. Vet. Immunol. Immunopathol. 39:225-236.

Hoek, A., V. P. M. G. Rutten, J. Kool, G. J. A. Arkestejin, R. J. Bouwstra, I. VanRhjin, and A. P. Koets. 2009. Subpopulations of bovine $\mathrm{WC}^{+} \gamma \delta \mathrm{T}$ cells rather than $\mathrm{CD}^{+} \mathrm{CD} 25^{\text {high }}$ FoxP3 ${ }^{+} \mathrm{T}$ cells act as immune regulatory cells ex vivo. Vet. Res. 40:06. https://doi .org/10.1051/vetres:2008044

Hope, J. C. D. Werling, R. A. Collins, B. Mertens, and C. J. Howard. 2000. Flt-3 ligand, in combination with bovine granulocyte-macrophage colony-stimulating factor and interleukin-4, promotes the growth of bovine bone marrow derived dendritic cells. Scand. J. Immunol. 51:60-66.

Howard, C. J., P. Sopp, J. Brownlie, L. S. Kwong, K. R. Parsons, and G. Taylor. 1997. Identification of two distinct populations of dendritic cells in afferent lymph that vary in their ability to stimulate T cells. J. Immunol. 159:5372-5382.

Jang, M. H., N. Sougawa, T. Tanaka, T. Hirata, T. Hiroi, K. Tohya Z. Guo, E. Umemoto, Y. Eibisuno, B. Yang, J. Seoh, M. Lipp, H. Kiyono, and M. Miyasaka. 2006. CCR7 is critically important for migration of dendritic cells in intestinal lamina propria to mesenteric lymph nodes. J. Immunol. 176:803-810.

Janovick, N. A., Y. R. Boisclair, and J. K. Drackley. 2011. Prepartum dietary energy intake affects metabolism and health during the periparturient period in primiparous and multiparous Holstein cows. J. Dairy Sci. 94:1385-1400.

Ji, P., J. K. Drackley, M. J. Khan, and J. J. Loor. 2014. Inflammationand lipid metabolism-related gene network expression in visceral and subcutaneous adipose depots of Holstein cows. J. Dairy Sci. 97:3441-3448.

Ji, P., J. S. Osorio, J. K. Drackley, and J. J. Loor. 2012. Overfeeding a moderate energy diet prepartum, does not impair bovine subcutaneous adipose tissue insulin signal transduction and induces marked changes in peripartal gene network expression. J. Dairy Sci. 95:4333-4351

Kenez, A., A. Kulcsar, F. Kluge, I. Benbelkacem, K. Hansen, L. Locher, U. Meyer, J. Rehage, S. Danicke, and K. Huber. 2015. Changes of adipose tissue morphology and composition during late pregnancy and early lactation in dairy cows. PLoS One 10:e0127208. https:/ /doi.org/10.1371/journal.pone.0127208.

Kohlgruber, A. C., S. T. Gal-Oz, N. M. LaMarche, M. Shimazaki, D. Duquette, H. N. Nguyen, A. I. Mina, T. Para, A. Tavakkoli, U. VonAndrian, A. S. Banks, T. Shay, M. B. Brenner, and L. Lynch. 2018. $\Gamma \delta \mathrm{T}$ cells producing interleukin-17A regulate adipose regulatory $\mathrm{T}$ cell homeostasis and thermogenesis. Nat. Immunol. 19:464-474.

Kolodin, D., N. van Panhuys, C. Li, A. M. Magnuson, D. Cipolletta, C. M. Miller, A. Wagers, R. N. Germain, C. Benoist, and D. Mathis. 2015. Antigen- and cytokine-driven accumulation of regulatory $\mathrm{T}$ cells in visceral adipose tissue of lean mice. Cell Metab. 21:543-557

Kotas, M. E., and R. Medzhitov. 2015. Homeostasis, inflammation, and disease susceptibility. Cell 160:816-827.

Lathrop, S. K., S. M. Bloom, S. M. Rao, K. Nutsch, C. W. Lio, N. Santacruz, D. A. Peterson, T. S. Stappenbeck, and C. S. Hsieh. 2011. Peripheral education of the immune system by colonic commensal microbiota. Nature 478:250-254.

Ley, K., C. Laudanna, M. I. Cybulsky, and S. Nourshargh. 2007. Getting to the site of inflammation: The leukocyte adhesion cascade updated. Nat. Rev. Immunol. 7:678-689.
Liu, L., M. Zhang, C. Jenkins, and G. G. MacPherson. 1998. Dendritic cell heterogeneity in vivo: Two functionally different dendritic cell populations in rat intestinal lymph can be distinguished by CD4 expression. J. Immunol. 161:1146-1155.

Loschko, J., H. A. Schreiber, G. J. Rieke, D. Esterházy, M. M. Meredith, V. A. Pedicord, K. Yao, S. Caballero, E. G. Pamer, D Mucida, and M. C. Nussenzweig. 2016. Absence of MHC class II on cDCs results in microbial dependent intestinal inflammation. J. Exp. Med. 213:517-534.

Lumeng, C. N., J. L. Bodzin, and A. R. Saltiel. 2007. Obesity induces a phenotypic switch in adipose tissue macrophage polarization. J. Clin. Invest. 117:175-184.

Luo, B. H., C. V. Carman, and T. A. Springer. 2007. Structural basis of integrin regulation and signaling. Annu. Rev. Immunol. 25:619647.

Macpherson, A. J., and T. Uhr. 2004. Induction of protective IgA by intestinal dendritic cells carrying commensal bacteria. Science 303:1662-1665.

Magnuson, A. M., D. P. Regan, J. K. Fouts, A. D. Booth, S. W. Dow, and M. T. Foster. 2017. Diet-induced obesity causes visceral but not subcutaneous lymph node hyperplasia, via increases in specific immune cell populations. Cell Prolif. 50:e12365. https://doi.org/ $10.1111 /$ cpr. 12365

Mann, S., F. A. Leale Yepes, T. R. Overton, J. J. Wakshlag, A. L. Lock, C. M. Ryan, and D. V. Nydam. 2015. Dry period plane of energy. Effects on feed intake, energy balance, milk production, and composition in transition dairy cows. J. Dairy Sci. 98:3366-3382.

Mathis, D. 2013. Immunological goings-on in visceral adipose tissue. Cell Metab. 17:851-859.

Mazmanian, S. K., C. H. Liu, A. O. Tzianabos, and D. J. Kasper. 2005. An immunomodulatory molecule of symbiotic bacteria directs maturation of the host immune system. Cell 122:107-118.

McKeever, D. J., N. D. Machugh, B. M. Goddeeris, E. Awino, and W. I. Morrison. 1991. Bovine afferent lymph veiled cells differ from blood monocytes in phenotype and accessory functions. J. Immunol. 147:3703-3709.

Mehta, P., A. M. Nuotio-Antar, and C. W. Smith. 2015. $\gamma \delta$ T cells promote inflammation and insulin resistance during high fat dietinduced obesity in mice. J. Leukoc. Biol. 97:121-134.

Merad, M., P. Sathe, J. Helft, J. Miller, and A. Mortha. 2013. The dendritic cell lineage: Ontogeny and function of dendritic cells and their subsets in the steady state and the inflamed setting. Annu. Rev. Immunol. 31:563-604.

Metlay, J. P., M. D. Witmer-Pack, R. Agger, M. T. Crowley, D. Lawless, and R. M. Steinman. 1990. The distinct leukocyte integrins of mouse spleen dendritic cells as identified with new hamster monoclonal antibodies. J. Exp. Med. 171:1753-1771.

Miyazawa, K., H. Aso, M. Honda, T. Kido, T. Minashima, T. Kanaya, K. Watanabe, S. Ohwada, M. T. Rose, and T. Yamaguchi. 2006. Identification of bovine dendritic cell phenotype from bovine peripheral blood. Res. Vet. Sci. 81:40-45.

Mucida, D., N. Kutchukhidze, A. Erazo, M. Russo, J. J. Lafaille, and M. A. Curotto de Lafaille. 2005. Oral tolerance in the absence of naturally occurring Tregs. J. Clin. Invest. 115:1923-1933.

Mukesh, M., M. Bionaz, D. E. Graugnard, J. K. Drakley, and J. J. Loor. 2010. Adipose depots of Holstein cows are immune responsive: Inflammatory gene expression in vivo. Domest. Anim. Endocrinol. 38:168-178.

Murphy, K. M., and S. L. Reiner. 2002. The lineage decisions of helper T cells. Nat. Rev. Immunol. 2:933-944.

Nishimura, S., I. Manabe, M. Nagasaki, K. Eto, H. Yamashita, M. Ohsugi, M. Otsu, K. Hara, K. Ueki, S. Sugiura, K. Yoshimura, T. Kadowaki, and R. Nagai. 2009. CD8+ effector T cells contribute to macrophage recruitment and adipose tissue inflammation in obesity. Nat. Med. 15:914-920.

Nussenzweig, M. C., R. M. Steinman, J. C. Unkeless, M. D. Witmer, B. Gutchinov, and Z. A. Cohn. 1981. Studies of the cell surface of mouse dendritic cells and other leukocytes. J. Exp. Med. 154:168187

Oeser, K., C. Schwartz, and D. Voehringer. 2015. Conditional IL14/ IL13 deficient mice reveal a critical role of innate immune cells for 
protective immunity against gastrointestinal helminths. Mucosal Immunol. 8:672-682.

Osborn, O., and J. M. Olefsky. 2012. The cellular and signaling networks linking the immune system and metabolism in disease. Nat. Med. 18:363-374.

Ospina, P. A., D. V. Nydam, T. Stokol, and T. R. Overton. 2010. Elevation of nonesterified free fatty acids and $\beta$-hydroxybutyrate in transition dairy cattle in the northeastern United States: Critical thresholds for prediction of clinical disease. J. Dairy Sci. 93:546554 .

Panduro, M., C. Benoist, and D. Mathis. 2016. Tissue Tregs. Annu. Rev. Immunol. 34:609-633.

Park, K. T., S. Burnett, and W. C. Davis. 2015. Development and characterization of a monoclonal antibody specific for bovine CD209. Vet. Immunol. Immunopathol. 163:216-220.

Park, K. T., M. M. ElNaggar, G. S. Abdellrazeq, J. P. Bannantine, V. Mack, L. M. Fry, and W. C. Davis. 2016. Phenotype and function of CD209+ bovine blood dendritic cells, monocyte-deriveddendritic cells and monocyte-derived macrophages. PLoS One 11:e0165247. https://doi.org/10.1371/journal.pone.0165247.

Rhodes, S. G., R. G. Hewinson, and H. M. Vordermeiser. 2001. Antigen recognition and immunomodulation by gamma delta $\mathrm{T}$ cells in bovine tuberculosis. J. Immunol. 166:5604-5610.

Round, J. L., S. M. Lee, J. Li, G. Tran, B. Jabri, T. A. Chatila, and S. K. Mazmanian. 2011. The toll=like receptor 2 pathway establishes colonization by a commensal of the human microbiota. Science 332:974-977.

Roussey, J. A., L. J. Oliveira, I. M. Langohr, D. Sledge, and P. M. Coussens. 2016. Regulatory $\mathrm{T}$ cells and immune profiling in Johne's disease lesions. Vet. Immunol. Immunopathol. 181:39-50.

Seo, K. S., W. C. Davis, M. J. Hamilton, Y. H. Park, and G. A. Bohach. 2009b. Development of monoclonal antibodies to detect bovine FoxP3 in PBMCs exposed to staphylococcal superantigens. Vet. Immunol. Immunopathol. 128:30-36.

Seo, K. S., S. U. Lee, Y. H. Park, W. C. Davis, L. K. Fox, and G. A. Bohach. 2007. Long-term staphylococcal enterotoxin C1 exposure induces soluble factor-mediated immunosuppression by bovine CD4 and CD8 T cells. Infect. Immun. 75:260-269.

Seo, K. S., J. Y. Park, W. C. Davis, L. K. Fox, M. A. McGuire, Y. H Park, and G. A. Bohach. 2009a. Superantigen-mediated differentiation of bovine monocytes into dendritic cells. J. Leukoc. Biol. 85:606-616.

Sonnenberg, G. F., L. A. Monticelli, T. Allenghat, T. C. Fung, N. A. Hutnik, J. Kunisawa, N. Shibata, S. Grunberg, R. Sinha, A. M. Zahn, M. R. Tardif, T. Sathaliyawala, M. Kubota, D. L. Farber, R. G. Collman, A. Shaked, L. A. Fouser, D. B. Weiner, P. A. Tessier, J. R. Friedman, H. Kiyono, F. D. Bushman, K. Chang, and D. Artis. 2012. Innate lymphoid cells promote anatomic containment of lymphoid-resident commensal bacteria. Science 336:1321-1325.

Sopp, P., and C. J. Howard. 2001. IFN $\gamma$ and IL-4 production by CD4 CD8 and WC1 $\gamma \delta \mathrm{TCR}^{+} \mathrm{T}$ cells from cattle lymph nodes and blood. Vet. Immunol. Immunopathol. 81:85-96.

Steinman, R. M., G. Kaplan, M. D. Witmer, and Z. A. Cohen. 1979. Identification of a novel cell type in peripheral lymphoid organs of mice. V. Purification of spleen dendritic cells, new surface markers, and maintenance in vivo. J. Exp. Med. 149:1-16.

Stephens, S. A., J. Brownlie, B. Charleston, and C. J. Howard. 2003. Differences in cytokine synthesis by the subpopulations of dendritic cells from afferent lymph. Immunology 110:48-57.

Strauch, A. U., F. Obermeier, N. Grunwald, S. Gurster, N. Dunger, M. Schultz, D. P. Griese, M. Mahler, J. Scholmerich, and H. C. Rath. 2005. Influence of intestinal bacteria on induction of regulatory $\mathrm{T}$ cells: Lessons from a transfer model of colitis. Gut 54:1546-1552.

Suzuki, S., S. Konnai, T. Shirai, Y. Sunden, C. N. Mingala, S. Murata, and K. Ohashi. 2013. Expression analysis of FoxP3 in T cells from bovine leukemia virus infected cattle. Microbiol. Immunol. 57:600-604.

Tamoutounour, S., S. Henri, H. Lelouard, B. de Bovis, C. de Haar, C. J. van der Woude, A. M. Woltman, Y. Reyal, D. Bonnet, D.
Sichien, C. C. Bain, A. M. Mowat, C. Reis e Sousa, L. F. Poulin, B. Malissen, and M. Guilliams. 2012. CD64 distinguishes macrophages from dendritic cells in the gut and reveals the Th1-inducing role of mesenteric lymph node macrophages during colitis. Eur. J. Immunol. 42:3150-3166.

Turnbull, E. L., U. Yrlid, C. D. Jenkins, and G. G. Macpherson. 2005. Intestinal dendritic cell subsets: Differential effects of systemic TLR4 simulation in migratory fate and activation in vivo. J. Immunol. 174:1374-1384.

Vailati-Riboni, M., G. Farina, F. Batistel, A. Heiser, M. D. Mitchell, M. A. Crookenden, C. G. Walker, J. K. Kay, S. Meier, J. R. Roche, and J. J. Loor. 2017. Far-off and close up dry matter intake modulate indicators of immunometabolic adaptations to lactation in subcutaneous adipose tissue of pasture-based transition dairy cows. J. Dairy Sci. 100:2334-2350.

Vailati-Riboni, M., M. Kanwai, O. Bulgari, S. Meier, N. V. Priest, C. R. Burke, J. K. Kay, S. McDougall, M. D. Mitchell, C. G. Walker M. Crookenden, A. Heiser, J. R. Roche, and J. J. Loor. 2016. Body condition score and plane of nutrition prepartum affect adipose tissue transcriptome regulators of metabolism and inflammation in grazing dairy cows during the transition period. J. Dairy Sci. 99:758-770

Van Dyken, S. J., and R. M. Locksley. 2013. Interleukin-4 and interleukin-13 mediated alternatively activated macrophages: Roles in homeostasis and disease. Annu. Rev. Immunol. 31:317-343.

van Liempt, E., C. M. Bank, P. Mehta, J. J. Garcia-Vallejo, C. S. Kawar, R. Geyer, A. R. Alvarez, R. D. Cummings, Y. V. Kooyk, and I. van Die. 2006. Specificity of DC-SIGN for mannose- and fucose-containing glycans. FEBS Lett. 580:6123-6131.

Vatier, C., S. Kadiri, A. Muscat, C. Chapron, J. Capeau, and B. Antoine. 2012. Lean VAT and SAT adipose tissue from lean women respond differently to lipopolysaccharide induced inflammation and glyceroneogenesis. Nutr. Diabetes 2:e51. https://doi.org/10 $.1038 /$ nutd.2012.29.

Vinay, D. S., C. H. Kim, B. K. Choi, and B. S. Kwon. 2009. Origins and functional basis of regulatory CD11c $+\mathrm{CD} 8+\mathrm{T}$ cells. Eur. J. Immunol. 39:1552-1563.

Weisberg, S. P., D. McCann, M. Desal, M. Rosenbaum, R. L. Leibelet, and A. W. Ferrante. 2003. Obesity is associated with macrophage accumulation in adipose tissue. J. Clin. Invest. 112:1796-1808.

Weitman, E. S., S. Z. Aschen, G. Farias-Eisner, N. Albano, and D. A. Cuzzone. 2013. Obesity impairs lymphatic fluid transport and dendritic cell migration to lymph nodes. PLoS One 8:e70703.

Welty, N. E., C. Staley, N. Ghilardi, M. J. Sadowsky, B. Z. Igyarto, and D. H. Kaplan. 2013. Intestinal lamina propria dendritic cells maintain $\mathrm{T}$ cell homeostasis but do not affect commensalism. J. Exp. Med. 210:2011-2024.

Wilson, R. A., A. Zolnai, P. Rudas, and L. V. Frenyo. 1996. T cell subsets in blood and lymphoid tissues obtained from fetal calves, maturing calves and adult bovine. Vet. Immunol. Immunopathol. 53:49-60.

Winer, S., Y. Chan, G. Paltser, D. Truong, H. Tsui, J. Bahrami, R Dorfman, Y. Wang, J. Zielenski, F. Mastronardi, Y. Maezawa, D. Drucker, E. Engleman, D. Winer, and H. M. Dosch. 2009. Normalization of obesity-associated insulin resistance through immunotherapy: $\mathrm{CD}^{+} \mathrm{T}$ cells control glucose homeostasis. Nat. Med. 15:921-929

Worbs, T., U. Bode, S. Yan, M. W. Hoffmann, G. Hintzen, G. Bernhardt, R. Forster, and O. Pabst. 2006. Oral tolerance originates in the intestine immune system and relies on antigen carriage to dendritic cells. J. Exp. Med. 203:519-527.

Xu, H., G. T. Barnes, Q. Yang, G. Tan, D. Yang, C. J. Chou, J. Sole, A. Nichols, J. S. Ross, L. A. Tartaglia, and H. Chen. 2003. Chronic inflammation in fat plays a crucial role in the development of obesity-related insulin resistance. J. Clin. Invest. 112:1821-1830.

Zúñiga, L. A., W. J. Shen, B. Joyce-Shaikh, E. A. Pyatnova, A. G. Richards, C. Thom, S. M. Andrade, D. J. Cua, F. B. Kraerner, and E. C. Butcher. 2010. IL-17 regulates adipogenesis, glucose homeostasis, and obesity. J. Immunol. 185:6947-6959. 